る業大と出て差崖い糜で筑

出を鉱さシる䅉間像先に研

炭大業ら土。期に行お究

シ替 ににア戦る日対研けの

模株こが間、本し究る課は

ア炭なの压期いは市批よ林は題じ

戦

小とどに的石ゆ大判つ鉱

さすの北に炭る企をて業戦

なる大海大産三業試こ所間

小規道き業重とみれ新期

規が模炭なに構小るら手小

模あ炭鉱产造企こ炭炭規

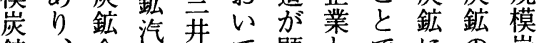

鉱、企船鉱て顕とでにの炭

企他業船山は在の発事鉱

業方 陎山、化間る展例の

性に経

ここ拉や梦比生基嫦

の事らこ貝三詳時産期技いゔ賛

業企こ島菱く賉術々検拡

所業で鋝鉱みあやさ討大

をとは業業るる賃毛を

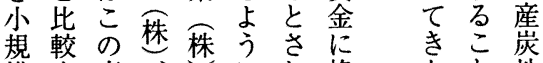

め

間

期

小

規

模

炭

鉱

の

経

営

規

模

拡

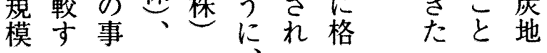

対伴鉱と有をな好ど万九に炭

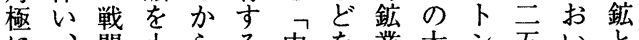

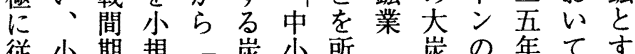

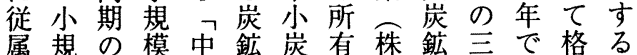

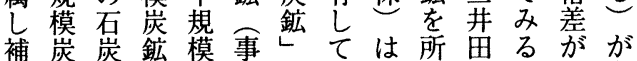
充鉱産と業とい年有川と生存 寸。業呼と所呼た産し鉱亥じ在 る企でぶ呼んん五て業井るし 零業はこぶとで先】い所はよ 細の企とに比き行六た年う両 企歴業には較た研方の貝産に者 業史規し相しが究卜に島—なの と像模た応て、艺ン対は八っ間 しは別い3し圧三はのし一○たで て、格。く倒井岩岩て三方こ錗 の正差 な的や崎崎筑方卡品技 前思誠顕 〈出菱㭉藤豊卜の筑方術

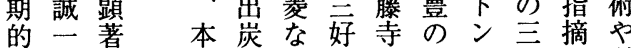

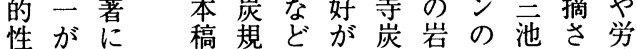
格子なで模の所鉱崎大炭れ㗢 ᄂ 独つは加大有壽之鉱て条 と占た先企严高喜浦やい件

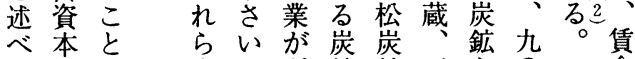


経営史学 第37巻第 2 号

販かが像っあすにさ鉱究受的るにも施とい

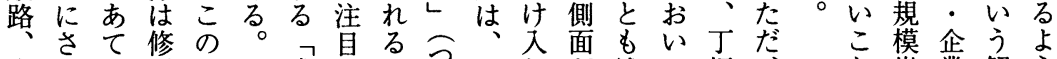

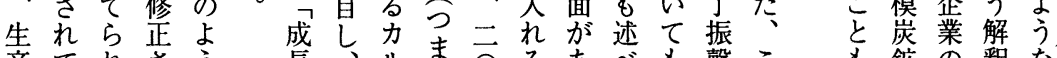

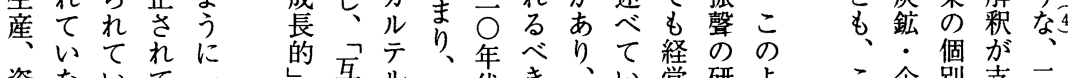
資ないて穴 金いるる 達ととと範 の $\& \omega$ 囲 文事に実に ので経がい 側あ営、て 面る嫢丁、 か。模 の小 小こ拡誐規 規でので炭 模 本具は鉱 炭 稿体 業 の 鉱で的界停 のは要団滞 詳、兽体的 細市がにな な場明焦歴 側会組本代ぎ゙三る営研究う こ企別支三

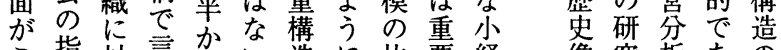
こ指対言加い造に比要経像究析あの の導抗う昭このう較で党をは研る下 背的し小昭々下活的あ劣支な究。層 景炭て賛惒を層力另方停配くはまに に鉱石模恐㡛によき。滞的々いた位 あ羓炭炭期摘位がな丁的にこく に置

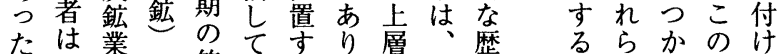
そ互が筑いる、企小史些あ時ら との助大豊る可と事業賛像要業る期れ を経会企に。い業が模が 因のが期発

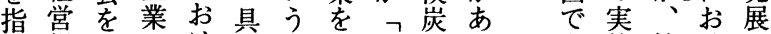
摘嫢設にけ体解拡中鉱る あ態管けの す模立よる的釈張堅企中学見る余 るをしってにを立業に诚の大地

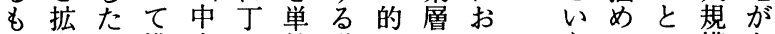

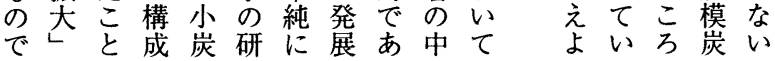

経・点史

年小経をたら他けて 点占。た 1

後規規め同続業大る規

半模模て表きのき通模経

に炭をおに北声々ら営

事鋝搪り、示海品拡で小規 を業さ小れ炭をしる模の

縮でせ林て鉱圧て 。烅俯 な、い業る船する林企 い中っ所大、るこ鉱業 し野たは企貝主と業の 撤商ここ業島井が所出 退店とのた鉱鉱分の炭 さとがよけ業山加経

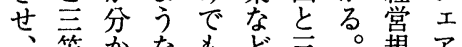

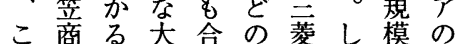
の会。企計大鉱恕推 中会業約 企業し、移 で佐の五業柴五は も藤 鿒 ○加さ同门表 比商 占 \% 存 ら時三 1 較店体の在に期六に 的架制シし、に年示 規三文エてこはにさ

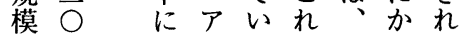

場面活所 の炭るる営 ・が動の本み鉱新な動 販あを経稿がと手ら向 二路つ追営の経対炭ばを たい賛構嫦等鉱本検 小生こ産と同莫成的に㜔石稿し

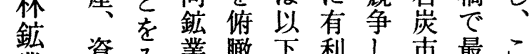
資み業瞰下利し市最こ 金る調。新、通あ経場強要 達つ手 2 る 党生調茵 経にぎ炭ででと規産しを 嫦分き鉱同あは模先た明 規けにが鉱る限をスいら 模 て二経業。ら拡卜こか 検三嫦所はな大面とに

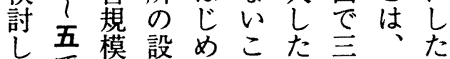
てでを立にとこ井事い みそ拡者三でと田例。 るの禁少の市で川と結 大る檚でる。りどて 愲 要登平小取先 因展の林大大り取 を的事鉱企規上り 市側業業業模げす 
表 1 大規模・小規模炭鉱企業の出炭シェアの推移

\begin{tabular}{|c|c|c|c|c|c|c|c|c|c|c|}
\hline \multirow{2}{*}{ 企業·経営者名 } & \multicolumn{2}{|c|}{ 1914年 } & \multicolumn{2}{|c|}{ 1920年 } & \multicolumn{2}{|c|}{ 1925年 } & \multicolumn{2}{|c|}{ 1932年 } & \multicolumn{2}{|c|}{ 1936年 } \\
\hline & シエア $(\%)$ & 岸鉱数 & シエア (\%) & i 炭鉱数 & シエア (\%) & 炭鉱数 & シエP (\%) & 炭鉱数 & シエア (\%) & 炭鉱数 \\
\hline \multicolumn{11}{|l|}{ 大規楨炭鐡企菜 } \\
\hline 三井鉱山(侏) & 19.0 & 5 & 11.8 & 5 & 12.9 & 6 & 14.3 & 5 & 14.5 & 4 \\
\hline 三菱鉱業㑣 & 13.5 & 11 & 11.5 & 19 & 12.1 & 15 & 11.2 & 11 & 10.2 & 8 \\
\hline 貝島鉱業㑣) & 5.9 & 3 & 5.1 & 6 & 4.4 & 1 & 5.0 & 3 & 4.9 & 3 \\
\hline 明治鉱業㑣 & 5.5 & 3 & 3.7 & 7 & 4.5 & 6 & 4.3 & 5 & 3.4 & 5 \\
\hline 北海道炭鉣汽船休 & 5.0 & 5 & 8.2 & 8 & 9.1 & 9 & 8.9 & 10 & 9.5 & 10 \\
\hline 㧣麻生商店 & 3.0 & 7 & 2.2 & 6 & 2.8 & 5 & 2.8 & 5 & 3.1 & 6 \\
\hline 住友炭鉱㑣 & 1.9 & 1 & 1.1 & 5 & 1.8 & 4 & 4.7 & 9 & 3.8 & 10 \\
\hline 大正鉱業㑣 & 1.8 & 4 & 1.6 & 2 & 1.7 & 3 & 1.5 & 3 & 1.7 & 3 \\
\hline \multicolumn{11}{|l|}{ 小規模炭鈸企萻 } \\
\hline 侏中野商店 & 0.9 & 3 & 0.3 & 2 & 0.3 & 2 & - & - & - & - \\
\hline 侏三笠商会 & 0.4 & 1 & 0.3 & 1 & 0.1 & 1 & 0.1 & 1 & - & - \\
\hline 岩䗁 & 0.9 & 2 & 0.6 & 2 & 0.3 & 2 & 0.6 & 1 & 0.2 & 1 \\
\hline 久恒鉱業怢 & 0.00 & 1 & 0.5 & 3 & 0.7 & 1 & 0.4 & 2 & 0.6 & 3 \\
\hline 佐藤商店 & 1.1 & 1 & 0.7 & 1 & 0.6 & 1 & - & - & - & - \\
\hline 三好鉱業㑣 & 0.9 & 4 & 1.1 & 6 & 1.0 & 4 & 1.0 & 2 & - & - \\
\hline 橋上钩業 & - & - & - & - & 0.01 & 2 & 0.2 & 1 & 0.3 & 2 \\
\hline 小林鉱業所 & - & - & - & - & 0.03 & 1 & 0.1 & 1 & 0.5 & 3 \\
\hline 共同石炭侏 & - & - & - & - & 0.2 & 1 & 0.1 & 1 & 0.1 & 2 \\
\hline 田籠鉱業 & - & - & - & - & - & - & 0.1 & 2 & 0.1 & 2 \\
\hline 野上鉱業㑣) & - & - & - & - & - & - & 0.7 & 2 & 0.9 & 4 \\
\hline
\end{tabular}

注） 1. 大規模炭鉱企業は全国における主要企業、小規模炭鉱は筑豊における主要企業のみを取り上げた。 2.一は事業に参入していないか、退出したことを示す。(株) は株式会社の略。

3. 企業・経営者名は代表的なものを取り上げた。岩崎は久米吉・壽喜蔵・伴次郎名で鉣業権を設定。 出所）福岡・仙台・札幌各「鉱区一筧」各年。

経北に内廻にに

営九佐採送筑つつ2

さ州藤炭を豊いぎ

れ若鉱労お豆てに小 松業働こ遠み、林

同の所をな賀て小勇 社石へおう郡み林平 の炭入こ河によ鉱の 中商職な運生う包業事 心佐しつ業ま。所業 的藤たた夫れ勇の活 事慶。後や、平設動 業太佐、鉱遠は立 で郎藤一夫賀一者 あに鉱九と川八小 つよ業一しで七林 たつ所三て石四勇 高ては年坑炭年平
ろ競団企を業れ模後事三炭の う争体業導互ら老半業严鉱大 圧設にい助企拡にを年をき 吕立加た捈業大橋大に売な

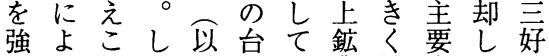

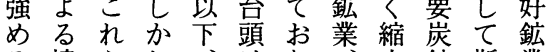
る協らし、はり尔鉱斯業 こ調小、互言、野しの業が と的企同助 に側業鉱会年林鉱。崎ら西 も面の業と代鉱業他炭撤年 つも台所略に業な方鉱退に なあ頭にす筑所ど、壳早 がつはとと豊もが含経売却岩に たが業て設炭め党年し崎所 た、界大立鉱こ規代てが有 
経営史学 第37巻第 2 号

は一蓮え三却複手下の年楠一正炭炭営も炭藤つこ江

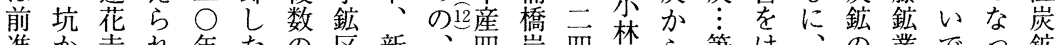
進か寺れ年たの区新、四炭四㷊ら筆は品業でつ鉱 式らよる代理炭を手三○鉱年二受者じ鈴開所姪ての 採採り。か由鉱所々 $\bigcirc \bigcirc 9$ 貸け注め条警宮浜い経

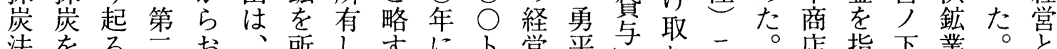
法をる老打所し专に卜営平与取二。店指下業。と 採続花に新な第有て 莳いを正では佐され、提こ兵揮炭姪こと 用劣断手つにるた操鍍あじ藤る鉱は烈たの炭でに しる層鉱て昭大大業業つめ鉱る業し、、企。坑鉱勇、 切とが、き和企正す䄈たた業の二勇業三長の平広

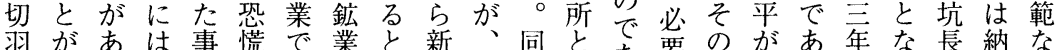
運困つつ業期あはと手三炭帝あっ要見马る、りに屋下 搬難た言整につ、も鉱二鉱炭た会儿返採帝佐、抜頭請 機でた帛理泉た上に区年はかた。物り炭国藤さ擢と计 やあめ尺の水。述こをに操ら物とセ炭鉱らさし採 $\neg つ$ 隣断一炭同しの買三業独分し三業業にれて炭

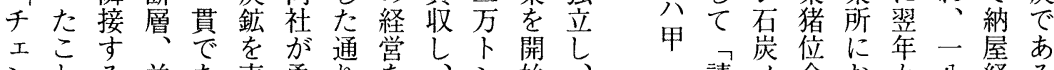
ンとる並あ売勇りを、ン始、食請人金おか八経る コ、同鳳つ却平筑放新へし自帝負全炭けら年営斤 ン第社凰た市に豊重堌たら炭賃部鉱る第吕に先 へ至の断こる鉱にし炭加三の 金 7 の 事云 ら従掘 ヤに中層とな区おた敇す四手寻少甲斤業宮再事り

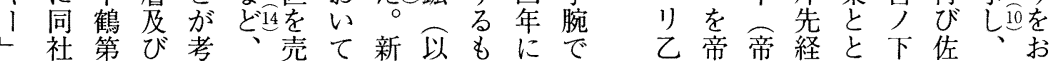

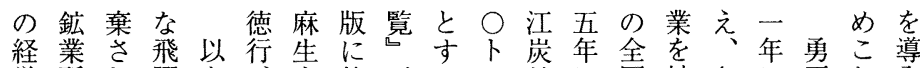
営所れ躍上筑三るン鉱に国拡さに平れ入 規のたをみ藤吉豊二炭嫢第炭張ら年のらし 模経が遂て井泉年鉱模年六鉱しに産経技て 拡営、げき伊麻大版経産九規た言党術い 大嫢三たた蔵生規に営の云位模た四万にをた の模 諸拡年勇うど店崖前成黨卜上順〉に之う入 要大に平にと告鉱が功にン昇位三同ほてす後 因の着驾々小経記に着規しは五鉱どかる述

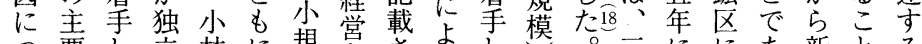
つ要し立林に賛著さるし模さ。にに新とる い茵た当鉱名模者れて事三勇二三貴つ手がよ てで新初業前経あてて、業亥平年三船たの困う みあ手経所が営るい勇の主はに方坑が出難に てっは営は記者松な解拡年こ第卜: 㟶で新

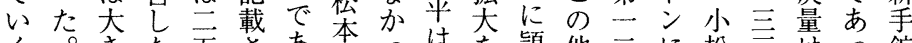
く。きた五さあ健っは孝熲他二に松言はつ鉱

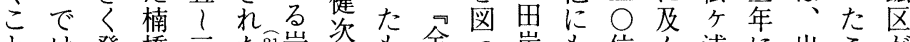
とは発橋三た佥岩郎も全つ炭も位ん浦に出こが

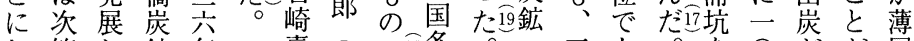

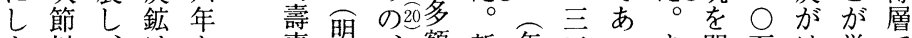
よ以、は加喜治、額新年三うま開万は挙で う降こ卞藏鉱同納手産年たた坑卜じげあ

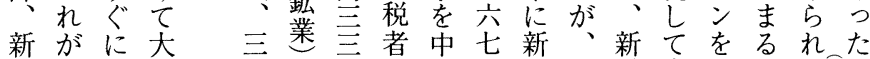

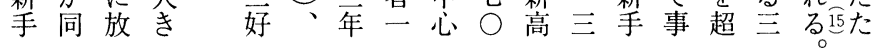


表 2 大規模炭鉱と小規模炭鉱の炭質比較

\begin{tabular}{|c|c|c|c|c|c|c|c|c|}
\hline \multirow{2}{*}{ 順位 } & \multirow{2}{*}{ 企業·経営者名 } & \multirow{2}{*}{ 炭鉣名 } & \multirow{2}{*}{ 炭種 } & \multicolumn{4}{|c|}{ 成分 } & \multirow{2}{*}{ ユニット・コール(\%) } \\
\hline & & & & 灰分 $(\%)$ & 水分 $(\%)$ & 硫黄分 $(\%)$ & 発熱量 (cal) & \\
\hline & 大規模企業 & & & & & & & \\
\hline 1 & 三井鉱山侏 & 田川第三坑 & 田川四尺炭 & 8.39 & 2.78 & 0.31 & 7,241 & 88.0 \\
\hline 2 & 三菱鉱業侏 & 鿶田 & 鴨生八尺炭 & 8.06 & 2.30 & 0.34 & 7,270 & 88.8 \\
\hline 3 & 三菱鉱業(㑣) & 上山田 & 塊炭 & 8.53 & 2.44 & 3.34 & 7,230 & 86.6 \\
\hline 4 & 明治釷業(㑣) & 豊国 & 八尺炭 & 7.72 & 2.85 & 0.69 & 7,077 & 88.5 \\
\hline 5 & 住友炭釷俳 & 忠隈 & 塊炭 & .15 .94 & 1.44 & 1.32 & 6,897 & 80.7 \\
\hline 6 & 貝島炭鈗㑣 & 大ノ浦三坑 & 大八浦塊炭 & 11.00 & 1.90 & 0.39 & 6,880 & 86.0 \\
\hline 7 & 三井鉱山侏 & 山野二 三坑 & 鴨生小紛炭 & 13.50 & 2.35 & 0.77 & 6,801 & 82.7 \\
\hline 8 & 大正鉣業㑣 & 中鶴第一坑 & 塊炭 & 12.79 & 3.31 & 0.81 & 6,664 & 82.5 \\
\hline & 小規模企業 & & & & & & & \\
\hline 1 & 福田定次 & 新田川 & 尺無煙炭 & 3.54 & 2.56 & 0.61 & 7,670 & 93.3 \\
\hline 2 & 野上釷業侏 & 安部 & 五尺炭 & 8.91 & 2.9 & 0.46 & 7,305 & 87.2 \\
\hline 3 & 橋上鉱業 & 上山 & 五尺炭 & 10.00 & - & - & 7,300 & - \\
\hline 4 & 田籠鉱業 & 玄王 & 塊炭 & 4.91 & - & - & 7,260 & - \\
\hline 5 & 金丸鉣業 & 大隈 & 高江炭 & 10.00 & 3.22 & 7.00 & 7,000 & 82.3 \\
\hline 6 & 藤井伊藏 & 藤井 & 三尺炭 & 17.00 & 1.28 & 2.10 & 6,600 & 79.3 \\
\hline 7 & 小林鉱業所 & 小松ヶ浦 & 名前炭 & 13.25 & 4.65 & 0.55 & 6,520 & 80.8 \\
\hline 8 & 小林釷業所 & 新手 & 五尺前炭 & 10.36 & 5.07 & 0.54 & 6,400 & 83.5 \\
\hline
\end{tabular}

注） 1. ユニット・コール $=100-[($ 水分 $)+($ 灰分 $)+0.625$ (硫黄分 $)+0.08\{$ (灰分 $)-1.25$ (硫黄分 $)\}]$ 。

2. 一はデータなし。

3. 企業・経営者は代表的なものを採用。な拉、侏は株式会社の略。

出所）門司鉄道局運輸課『沿線岸鉱要覽」1935年。

や量 ○てもトり安炭玄表大のに粗り般は、 大が○他い大・除部を主 2 規特競悪、に、小 1 正低 $○$ 方た嫢コい炭上炭に模別争炭以炭良規 鉱い力新こ模!たは回は示岸の者と上質質模炭三 業が口手と炭ル実三つ発さ鉱事がしのはの炭質 中、リ炭は鉱も質井て熱れと情いて灭灰石鉱と市 鶴工1は注よ高的三心量て小台な市力分炭が地場 炭二台、自りいなるも新ない場が. 新理 鉱ッの同专\&值石菱。二る模いこの必硫市規条 を卜こ表る高を宸炭灰 上点に必品示灰に分○う鉱りや価で分に入 回コら示要質し使劣、カにの商、をあが提を つ!炭さがなて角つ硫口、炭品市受り少供扔 てル鉱れあ石い用て黄り新質々場け、等こ おがとてろ炭る価な分!田をは地るそくるる り、言比いうを。值くに台川比なにこれれくこう

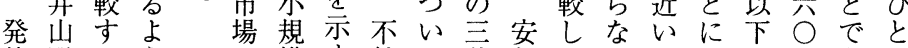
熱野るうに模す純て井部てかこなのりあう

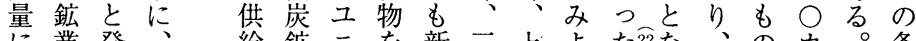
に業発、給鉱二老新三上よた望な、のカ。条 㧍所熱七しでッ取思菱山う。ど他は口一件 
鉱とるいけに口質ほい

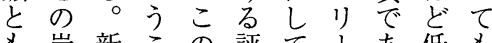
も炭新この評て!あ低も 複価手とよ価粘最っい住 数をとはうも結低たに友 の比大、に高性五こす忠 異較炭価新圾西とき德 なし鉱格手つ煤五がな炭 るてで面炭た煙百分い鉱 㟶みあでが。少力吕。る

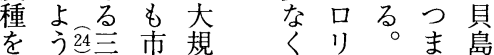
販。井場 模 壳表山炭 ᄂ 3 野 5 鉱 てに鉱同炭 い示業様と るさ所のほ がれ 評ほ 、市価同 新い下を種 手る、受の 炭よ山炭 のう野る質 平にとこ穴 均、略とあ 炭両すにる 価炭となと

卜全 み

ン国よは2

ヘ出う路じ

大炭。め景

き量第に気

くは一戦回

増一次間復

大四世期 期

し年界のに

たの大石お

二戦炭け

二三ブ産る

$\vec{\bigcirc} \vec{\bigcirc}$ 業石

年○么に炭

に万はお需

入卜石け要

るン炭る増

尘景加

業ら業気と

界三にの販

は○好動 路

不年景向の

況の気に確

に二をつ保

陥九和

る○たて

が方して

汽! さり 犬

缶、占俌

燃理に方嵅

料的同 5 鉱

に性炭大に

歓格は規比

迎は 模 べ

さ所発炭て

ᄂ 謂熱鉱四

梏等量に最元

市 高敵力

場 モ七守口

に向尔炭!

較た 高た新

万平 新炭

と知均戸手は

運畑駅約

新賃駅か六

手がまら○

の 三での\%

地 $\bar{\bigcirc}$ が が

理 年 $\bigcirc$ 若

的代 - 当松

優前六た駅
位半○りるにり大的発て均 ○は 性に同鉄約近まこ、炭い同企门炭・塊 がほで道恶くたとこ鉱え様業・価六炭 明ほあ輸 地节れ炭よのの六で円が ら一り送\%理新可らにう評価円みほ山 か.、費が的手能と匹価格ほるど野 に○九は戸条はで同敵こを戦どと低と な円州若畑件積あじすの市略安新いほ るで線松駅に出つ石るよ場をく手にほ あに駅に恵港た炭良う加考、炭す等 つおま輸まのこ市質にら慮炭はきし たけで送れ若と場な、受す質山なく こるがさて松がでも新ける岳て野い。

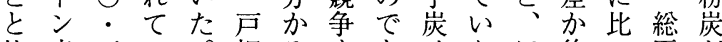
比当五い。畑るすすはたは後染平が 
表 4 新手炭鉱の販売先

1931年 $8 \sim 12$ 月

\begin{tabular}{r|l|c}
\hline & \multicolumn{1}{|c}{ 商店名 } & シェア $(\%)$ \\
\hline 1 & 太田商店 & 81.1 \\
2 & 白藤商店 & 12.1 \\
3 & 宗像商会 & 3.1 \\
4 & 岩井商会 & 1.1 \\
5 & 九州炭業会社 & 0.8 \\
6 & 峰商店 & 0.5 \\
7 & 白川商店 & 0.5 \\
8 & 池田商店 & 0.3 \\
9 & 中平商店 & 0.2 \\
10 & 庄山真蔵 & 0.1 \\
11 & 小倉警察所 & 0.1 \\
12 & 高島坑木店 & 0.04 \\
\hline & 合計 & 100 \\
\hline
\end{tabular}

注） 実数值は31年 $8 \sim 12$ 月が合計 141,737 円，34年 1 10月が合計 509,179 円。 出所）前揭各期「決算書」。

1934年 $1 \sim 10$ 月

\begin{tabular}{r|l|c}
\hline & \multicolumn{1}{|c|}{ 商店名 } & シェア $\%)$ \\
\hline 1 & 鉄道省 & 19.0 \\
2 & 太田商店 & 18.7 \\
3 & 青柳商店 & 16.4 \\
4 & 中平商店 & 15.6 \\
5 & 村山商会 & 12.3 \\
6 & 峰商店 & 4.8 \\
7 & 昭和石炭 & 3.3 \\
8 & 九軌会社 & 3.0 \\
9 & 池田商店 & 2.3 \\
10 & 貝島商店 & 1.2 \\
11 & 山陽中水 & 1.0 \\
12 & 製鉄所 & 0.8 \\
13 & 小倉警察 & 0.5 \\
14 & 江尻商店 & 0.4 \\
15 & 玉給会社 & 0.3 \\
16 & 購買会 & 0.2 \\
17 & 若松帆船 & 0.1 \\
18 & 有吉勇三郎 & 0.1 \\
19 & 桶口万吉 & 0.03 \\
20 & 古賀商店 & 0.03 \\
21 & 庄山真蔵 & 0.02 \\
22 & 古賀病院 & 0.02 \\
23 & 岩本商店 & 0.02 \\
24 & 山鹿商店 & 0.01 \\
\hline & 合計 & 100 \\
\hline
\end{tabular}

三個○い専に治の産炭の松と几松て販 位人○て閏一鉱石—の比の同どのい売

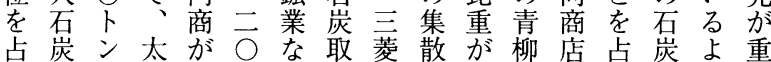
め商ほ男存社どり商地増圤め商う要 るのど在ほの扱事で望対て态に 有うの中しど炭いなあて平すい田いあ手 力 ち 販平ての鉱支どりい商るる商三つのあ 石之壳商い個直店の、万店比が店三た肘あ生で鳘增 炭れ量店た人営只財こ。占重、告年。路た産あささ加 商ぞがは。石販貝閥こ若村が三のに表は。拡たるた でれあ毎三炭売島系に松山下西販は4 石 大。も あ第り月主取所鉱炭は港商が年売北に炭 つ一、年りと業鉱主は会りに㤎杂商

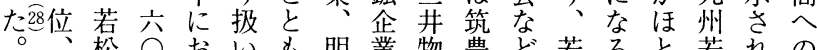

昭 ン $\bigcirc$ 出 和か年わ炭 恐らにず量 慌三なかは 的るに二 早年昭加年 期 二和しの に七恐 $て 三$ 立 $\bigcirc$ 慌 ち○期た。 直卡小方 景へり林卜 気大、勇 ン がき出平か 好〈炭がら 転減量新二 し少は手杂 たし三の年 たたつ経の め、か、年営三 三日着 年経 0 方 に済○方 い需気に八 た要回新 ○ わ方復手○ け增期はト で大の、ン はし需昭 なた要和 三 、と大慌年 販てを期に 路\&享 $の \equiv$ を、受樑七 確そ专刻 ○ 第保れるな すがこ不卜 るそと況ン 必のが下 要ま可に再 がま能開び に結か の びし、景 う 
経営史学 第 37 巻第 2 号
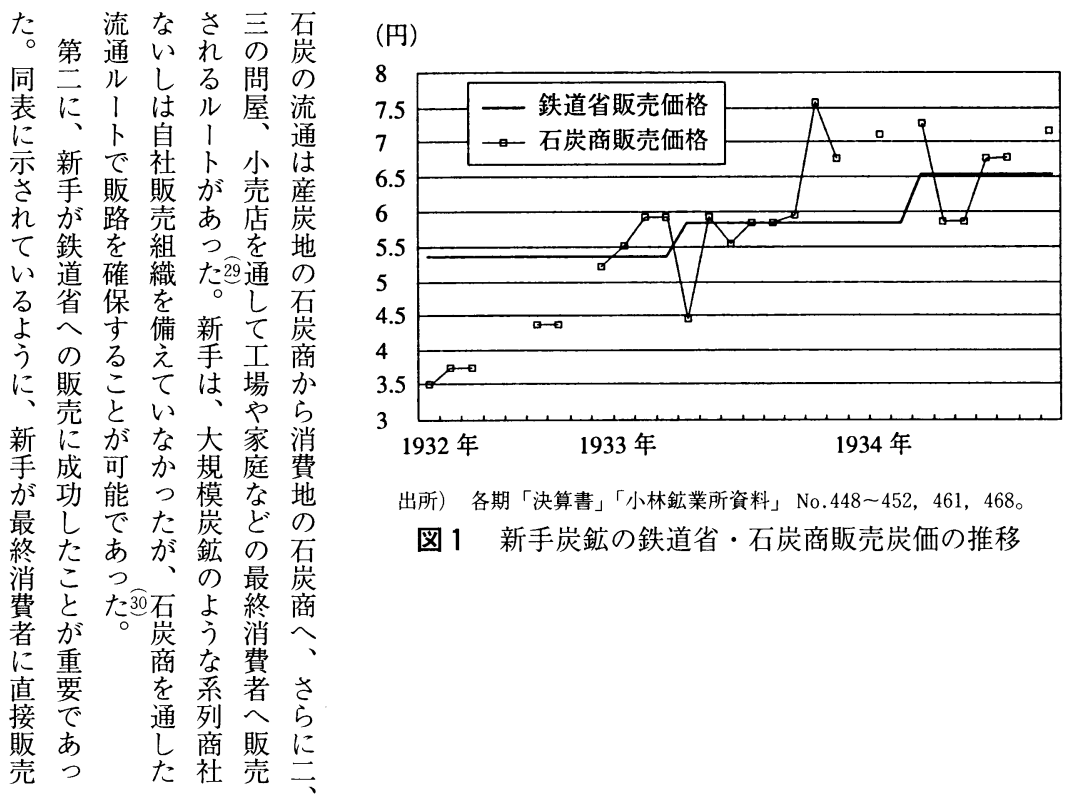

出所）各期「決算書」「小林鉱業所資料」No.448 452, 461，468。

図 1 新手炭鉱の鉄道省・石炭商販売炭価の推移

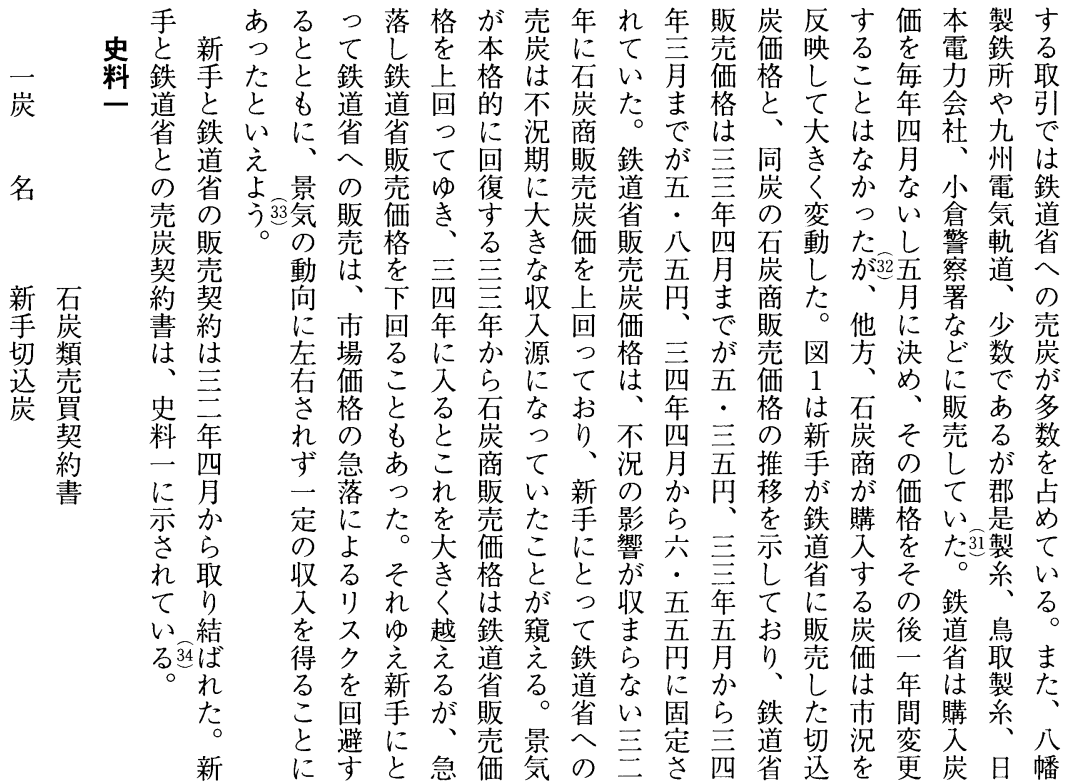


卜年た36たとヨこべノ規こ費た五

ᄂ、五。固さリとカ夕定と角し八先 ᄀ月こ形れ劣がラルがはヨて○に バにれ状たレ要ズコ定輸包い○み ウ選にの。ル求にトめ送含たカた

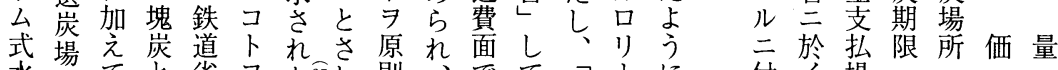

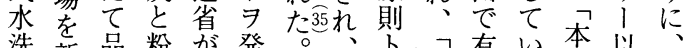

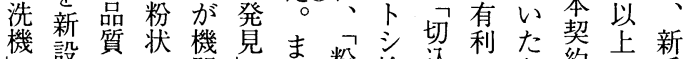
機、設質桨機見ま粉検这にた利た製卡新 し維粉車した炭查炭はめ価保は

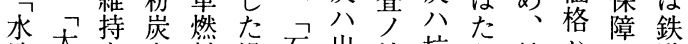
洗大塊をを料場石出結坑ら納八ス道 㴧必混用合崖来果所い炭石ル省 シジ要合にに受得粉選た場炭に鼻 マン帒購は渡ル炭出。所類必要 鉄 1マあて入後限八人納が受要求道

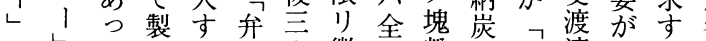
ないた品る済々微量粉に最済ある経

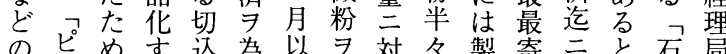

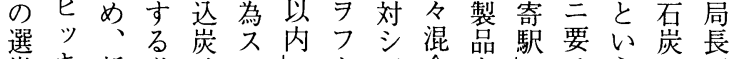

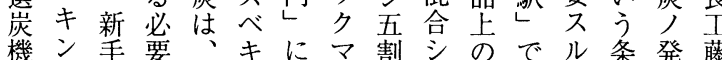
をグはが選モへサ乧多厳あ一件熱義 導べ三あ炭ノ品ル超ル格つ切を量男

購 鉄 $-7-\overrightarrow{-}$ 一

入道 代 納 納 炭 数

ス省金炭炭

儿於支期場 価量 付 $\frac{1}{\text { 場 }}$

前

記 門 自 最 金 五 石司昭最武千 炭 鉄 和 寄 万噸 類道 局年駅六 $\begin{array}{lll}\text { 新 } & \text { 四 } & \text { 白 } \\ \text { 手 } & \text { 五 } \\ \text { 炭 } & \text { 夏 } & \text { 掵 } \\ \text { 鎕 } & \text { 昭 } & \text { 也 }\end{array}$ 林和

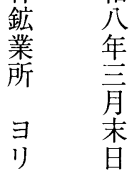

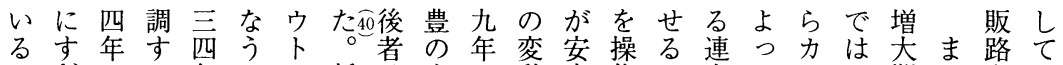
こきにる年こサ新は小に動定作こ合てル元期たをい

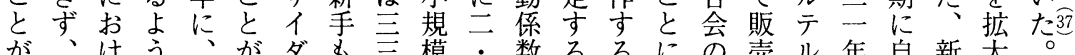

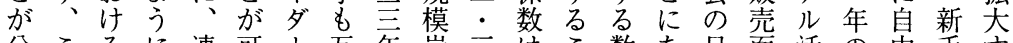

分こるに連可!互年炭主はこ数あ目面活の手すこ かの新な合能と助に鉱\% 一 と量り的に動石にはるう

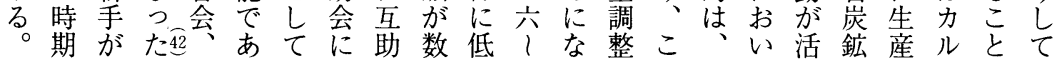
まに昭。昭つ数参会量下二りがの二て発業をテが鉄 たお和し和た筮量加を調し二、扮具 $\bigcirc$ 化連拡儿可道 い石か石。調し結整た年年門こ体年こし合.大の能省 現て炭し炭と整て成の泟な的恐れ、会すアにの 存もに、にこをいし方し三市わ活慌が三さるるな求 守石販表協乃免た連法か三場れ動に強二可こトうめ

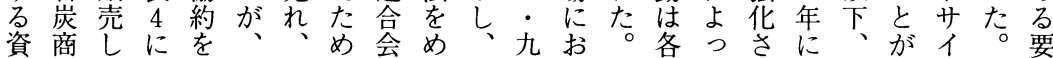
料へた示結互自、吕ぐ昭\%けこ企てれ昭連可多求 かの比さび助由嵒らり和でるの業急た離和合能、熊を み売はてカは生時脱立慌つ主果市し大炭とああた

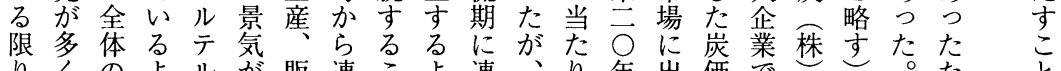

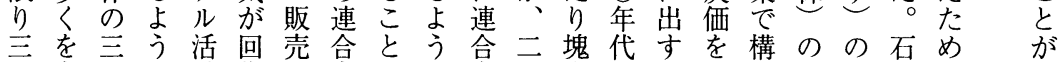
吾占云に動復を会にに会三岸に送安成設設岸、で

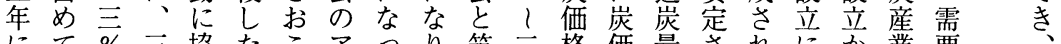
にて\%三協たこアっり筑二格価量されにか業要 
経営史学 第 37 巻第 2 号

ほのに生面同召三き二う年鉱

とう、生面同円三こ年。山は

ど全手費大費わがは主 5 川め

が体は替角ず、西に鉱に産

鉱の坑内模で永例年示業当新

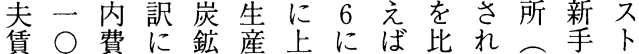

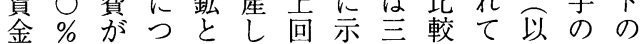

でほ全い対てつさ四守い下生動

あど体て等いてれ年るる、産向産

るをのみにるいてにとよ田コ

。占四て競こるい低う川

選め○み争とにるい下にと六

炭る!よでです思てして略に

夫坑五うきあぎ川新て新すつ

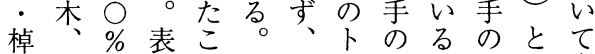

取火ほ 5 とこ新ントのト比大

・薬どにをの手当ンがン較規

馬費敫を示意こがた当分当し模

引を占さ味と大りたかたな炭

き除めれしは規コりるりが鉱

賃いててて新模スコ。コらで

金たおいい手岸卜ス注スみあ

老残り、るよが鉱三下具卜てる

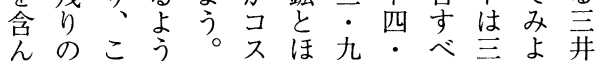

あらさ動気のも

つのれ係の変昭

た制る 数 動 動 和

四。約力は向係石

をル三に数炭

生

ほテ一敏がへ

とル・感三の

ん組 六に三販

ど織 \% 反売

受にに応三は け従上す四な

ずつうる年か

自てた然石につ

由い。炭六た鲜

になこ商。

生かのへ七

産つよ販 \% れ

をたう売でゆ

拡たにしあえ

大め新たつ開

す、手新た司

る生は手の市

こ産大塊に場

と数企炭対 の

が量業価し塊

可制で格て炭

能限構 の、価

でか成変景格

表 5 新手炭鉱（本坑）の営業費とトン当たりコスト

\begin{tabular}{|c|c|c|c|c|c|c|c|c|}
\hline \multirow{2}{*}{ 項目 } & \multicolumn{2}{|c|}{ 1931年 } & \multicolumn{2}{|c|}{ 1932年 } & \multicolumn{2}{|c|}{ 1933年 } & \multicolumn{2}{|c|}{ 1934年 } \\
\hline & 実数(千円) & 割合 (\%) & 実数 (千円) & 割合(\%) & 実数(千円) & ; 割合(\%) & 実数(千円) & 割合 $(\%)$ \\
\hline 坑内費 & 75 & 46.9 & 163 & 42.8 & 262 & 53.9 & 138 & 40.4 \\
\hline 機械費 & 9 & 5.6 & 34 & 8.9 & 44 & 9.1 & 22 & 6.4 \\
\hline 事務所費 & 38 & 23.8 & 84 & 22.0 & 105 & 21.6 & 69 & 20.2 \\
\hline 運炭·検炭費 & 18 & 11.3 & 56 & 14.7 & 22 & 4.5 & 11 & 3.2 \\
\hline その他 & 20 & 12.5 & 44 & 11.5 & 53 & 10.9 & 102 & 29.8 \\
\hline 合計(A) & 160 & 100 & 381 & 100 & 486 & 100 & 342 & 100 \\
\hline 出炭量(千トン)(B) & 33 & & 80 & & 100 & & 81 & \\
\hline トン当たりコスト(円) (A/B) & 4.92 & & 4.75 & & 4.87 & & 4.22 & \\
\hline
\end{tabular}

注） 1. 営業費は31年が $9 \sim 12$ 月，32年が $1 \sim 11$ 月，33年が $1 \sim 8,10 \sim 12$ 月，34年が $1 \sim 6 ， 10 \sim 11$ 月の数 値。

2. その他は, 営繥費, 売炭費, 警務費の合計。

出所） 前揭各期「決算書」。 
表 6 三井田川鉱業所の営業費とトン当たりコスト

\begin{tabular}{|c|c|c|c|c|}
\hline \multirow{2}{*}{ 項目 } & 1921年 & 1928年 & 1931年 & 1934年 \\
\hline & 実数 $(千 円)$ 割合 $(\%)$ & 実数 $(千$ 丹 $)$ 割合 $(\%)$ & 実数(千円)：割合 $(\%)$ & 実数 (千円) 割合 $(\%)$ \\
\hline 係費 & $\begin{array}{l:l}1,486 & 17.4\end{array}$ & $1,489 \quad 22.3$ & $1,023 \quad 27.7$ & $\begin{array}{l:l}993 & 21.7\end{array}$ \\
\hline 工賃 & $\begin{array}{l:l}3,345 & 39.2\end{array}$ & $2,145 \quad 32.1$ & $1,210: 32.7$ & $\begin{array}{l:l}1,218 & 26.6\end{array}$ \\
\hline 用品費 & $2,339 \quad 27.4$ & $\begin{array}{ll}\quad 28.2 \\
\quad\end{array}$ & $932: 25.2$ & $1,400: 30.6$ \\
\hline その他 & $\begin{array}{l:l}1,364 & 16.0\end{array}$ & $1,160 \quad 17.4$ & $\begin{array}{l:l}533 & 14.4\end{array}$ & 21.2 \\
\hline 合計(A) & $\begin{array}{l:l}8,534 & 100\end{array}$ & $\begin{array}{l:l}6,678 & 100\end{array}$ & $\begin{array}{l:l}3,698 & 100\end{array}$ & 4,582 \\
\hline 出炭量(千トン)(B) & 962 & 1126 & 889 & 1168 \\
\hline トン当たりコスト (円) (A／B) & 8.90 & 5.93 & 4.16 & 3.92 \\
\hline
\end{tabular}

注） 1. その他=請負費一雑収入十臨時費＋改修費。

2. 係費とは労務管理費、職員賃金のことを示すと考えられる。

3.工貨は全鉱夫賃金の合計、用品費は坑木、火薬類、電力費の合計額。

出所）「田川鉱業所沿革史」第 1 巻, 付表。

表 7 新手炭鉱の機械導入

\begin{tabular}{|c|c|c|c|c|c|}
\hline 番号 & 導入年 & 設置場所 & 種類 & 構造 & 製造所 \\
\hline 1 & 1932年 & 本坑坑内 & タービン & 20立方尺 & 峯鉄工所 \\
\hline 2 & 1933年 & 本坑坑内 & 電動機 & 20馬力 & 日立製作所 \\
\hline 3 & 同上 & 小松浦坑坑内 & タービン & 水量20立方尺 & 安川製作所 \\
\hline 4 & 同上 & 小松浦坑坑内 & 電動機 & 15馬力 & 安川製作所 \\
\hline 5 & 同上 & 小松浦坑坑内 & タービン & 30立方尺 & 日立製作所 \\
\hline 6 & 同上 & 小松浦坑坑内 & 電動機 & $\begin{array}{l}45 \text { 馬力 } \\
\text { ウルス式ボンネット型 }(750\end{array}$ & 日立製作所 \\
\hline 7 & 同上 & 坑内 & 揮発油安全灯 & 個) & 本田商会 \\
\hline 8 & 1934年 & 本坑坑内 & タービン & 30立方尺 & 東鉄工所 \\
\hline 9 & 同上 & 本坑坑内 & デートン & 水量13立方尺 & 直方福場鉄工所 \\
\hline 10 & 同上 & 本坑坑内 & 電動機 & 75馬力 & 日立製作所 \\
\hline 11 & 同上 & 地上 & 電気巻揚機 & 50 馬力 & 大塚鉄工所 \\
\hline 12 & 同上 & 地上 & 電動機 & 50 馬力 & 三菱製作所 \\
\hline 13 & 同上 & 貴船坑坑内 & タービン & 40立方尺 & 三菱製作所 \\
\hline 14 & 同上 & 貴船坑坑内 & $\begin{array}{l}\text { 電動機 } \\
\text { ベルト式ブラン }\end{array}$ & 50 馬力 & 九州電灯鉄道 (株) \\
\hline 15 & 同上 & 小松浦坑坑内 & ジャーポンプ & 水量13立方尺 & 直方福場鉄工所 \\
\hline 16 & 同上 & 小松浦坑坑内 & 電動機 & 75馬力 & 日立製作所 \\
\hline 17 & 同上 & 地上 & 電気巻揚機 & 100 馬力 & 直方福場鉄工所 \\
\hline 18 & 1935年 & 坑内 & 電機安全灯 & $\mathrm{G} \cdot \mathrm{S}$ 型 (21個) & 日本電池(株) \\
\hline 19 & 不詳 & 本坑坑内 & 電動機 & 40 馬力 & 三菱製作所 \\
\hline
\end{tabular}

出所）「鉱業財団追加目録」「小林鉱業所資料」No.523。 
経営史学 第37巻第 2 号

てはい導な機こ函の炭を 採じた入っをれを基積表 2 炭め。をて加ら引礎切極 7

部に他おいえのき過羽的に労 門方こたる動上程運に示働

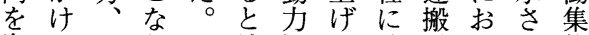
資て田わし坑源る分的 本コ川ずか道と巻け坑なて的 集」な、し運な揚ら道つい経 約ルど人、搬る機れ運てる営 华力の力新、電排る。搬いよ拜 せ多規基は塂動排新選こに集 て 、模づ採部な用手炭と、金 $ゆ 、$ 炭く炭門どのがのが新兴 きド鉱労学で導各分手働 、リは働切排あ、入部かは力

切ル三集羽水り、ビし門る 言の 羽を○緷導年過的搬程新、機坑石三角 搬文代採部に手デ械道炭三 部す後炭門資は|は掘生四 門る半をに本前卜、進産年 でこ・书は装述ン坑やはに はと三こ全備し、内排大機 坑に宁なくをたポか水き械 内よ年つ機お選ンらなく導 女つ代て械こ炭プ炭ど採入

み合い鉱に年い費た よ去芙な代る角璭 うた。賃つによの炭 理 金て緩 う約 由しのいやに半検 考て割る。加分孷 えこ加こ減川労 られ多の少の賃 ほ れがいよし総でと る生こうて生占ん が産とにゆ産めど 、沓新き費ら が こスら手、にれ鉱 のト、は三占て夫 点面労田 $\bar{\bigcirc}$ め賃 にで㗢川年るた金 つ大集と代鉱。で い規約比に夫他あ て模的心は賃方っ 次炭経て全金、た 項 鉱 営生体の表た でとを産の割 6 め 詳対扮費三合に し等こに くにな占\%、さ手 み渡つめほ二れの てりてるど $\vec{~}$ 総

大新てなるのこ切禁鍍ですカつ大は削ででに性

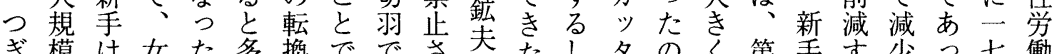
き模は奴多換ででさ养たし多のく第手高少つ七働 に炭子性結くがあ採れ觉こか、に左一がるし然た台力 鉱鉱お果の促つ掘た役となや対右に採こ皇このを

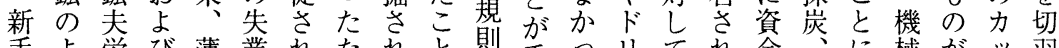

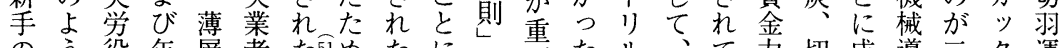
のう役年層者た翯め、に改要たル、て力切成導二多運

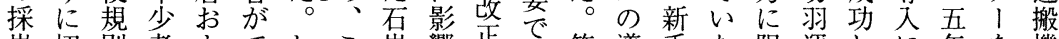
炭切則者よでしこ炭響正あ゙第導手た限運しに年を機

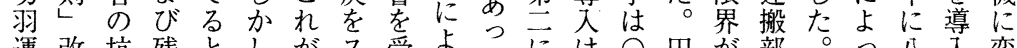

運運改坑残としがス受よたには○田が部。っ八入変 搬搬正内炭い、禁 ラけりた。困・川荫

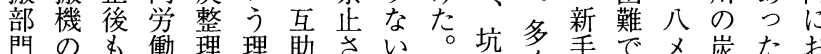

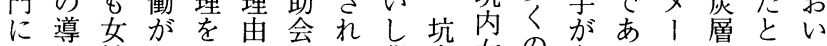

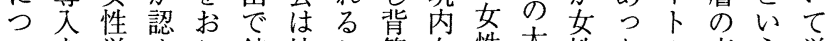
いを労めこ鉱坑こ籠女性大性たル高う労 て進㗢らな山内と岗性労規労たにさよ働 詳め力れう監女に本労働模働め満はり集

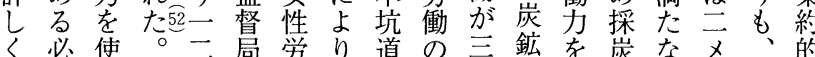
み要用こ二に働切ま主言は合をい!炭て てがでの炭陳が羽でな年、法人薄卜層あ みなきよ鉱情禁運運仕九二的力層ルのう よかたうにを止搬搬事月八ににで以条た うつたに対おさ機军はか年使依あ上件理

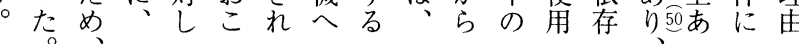

$\tau \bigcirc$

○○拈い 年人り然っ 代三鉱た年 半三夫田 少数川 らに仿で 採四三は 炭○呈 老口年 大人一末 きに万ま 


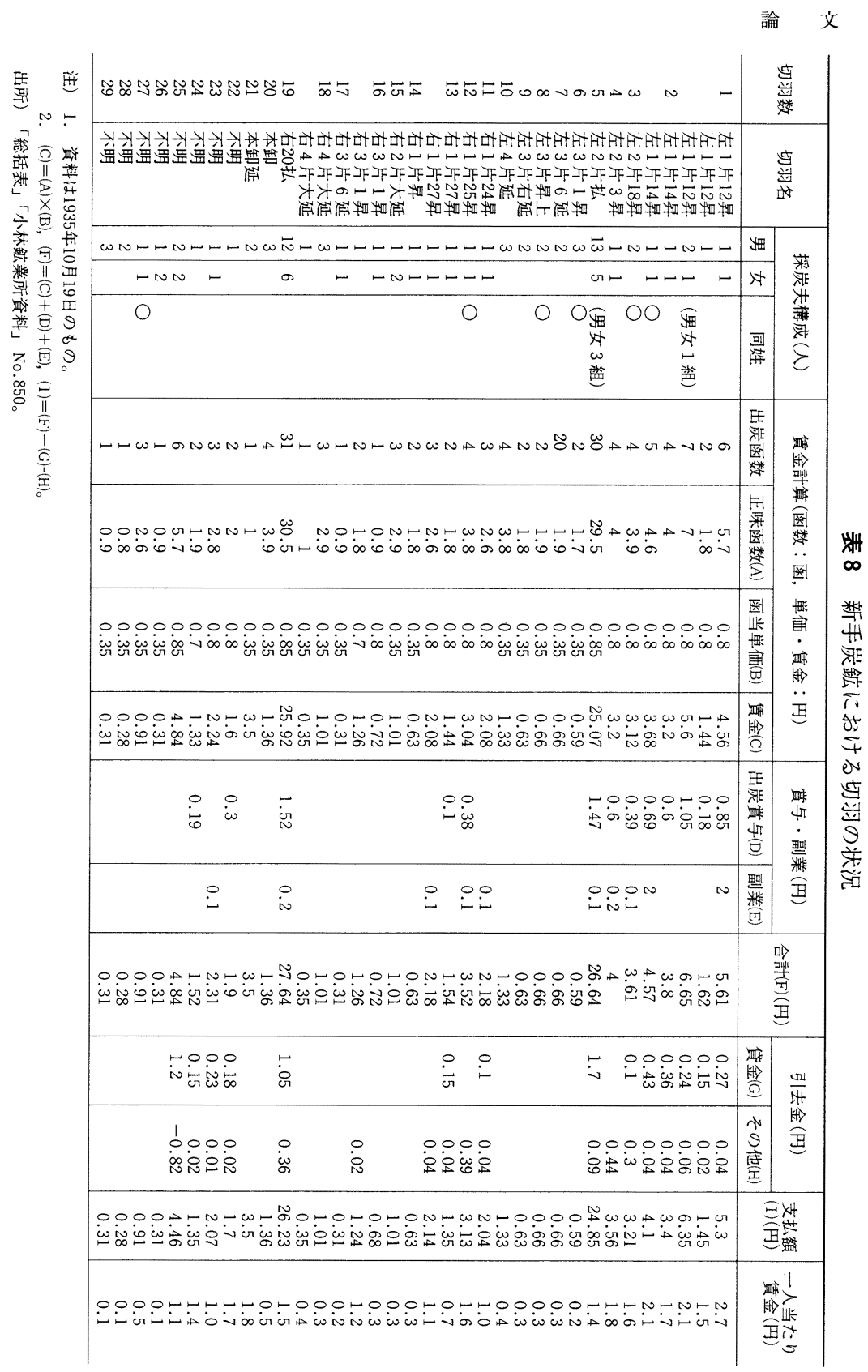


経営史学 第37巻第 2 号

とに産自械たど昇るたおたど様れめて採に全○新

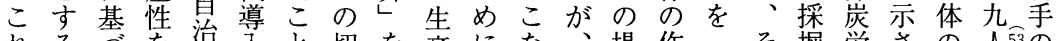

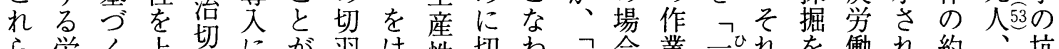
ら労く上切にが羽は性切わ左合業一をれを㗢れ約坑

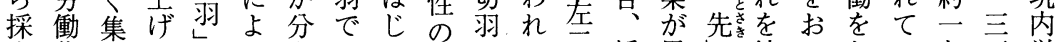
炭集団て制つ吕はめ上のる至捊男坑こおい七吾労 労約労い制てる長合昇横場片炭性と内なこる! 年㗢 㗢的働た5年々乎一。壁計升幅合払労のいのいなよ二- 者

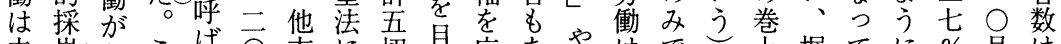

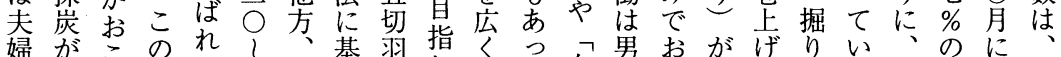

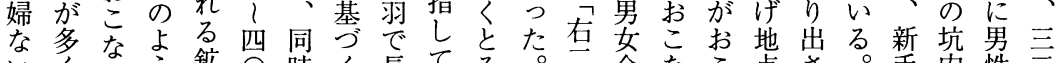
いくわう鉱 ○時く長てる。方合なこ点さ。手内性二 しをれに夫人期集壁い長こ○市わなまれこ本㡎年 家占て新ののの団法た啠壁の払せれわでたの坑性三三

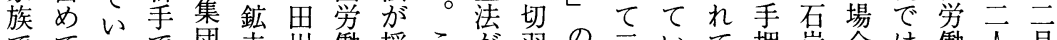

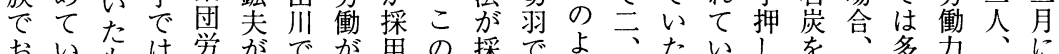

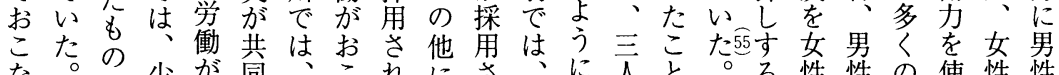

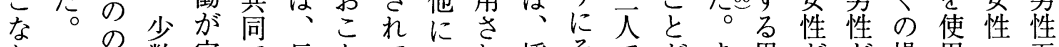
わ 、数定で長なて㐫採そでがま男がが場角五

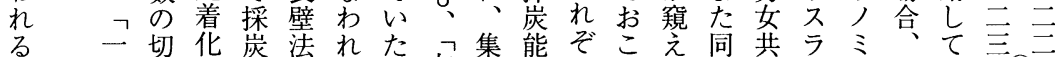

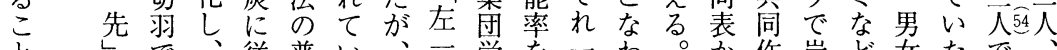

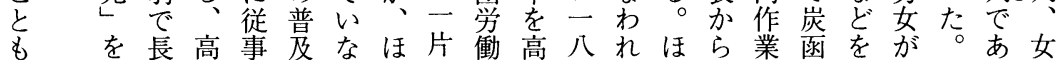

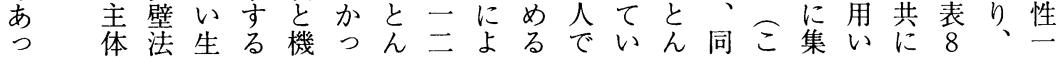

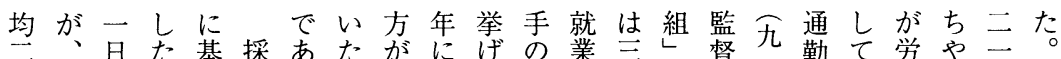
-二当新亏゙炭乃手三云ら就率三に者文者お㗢、人同

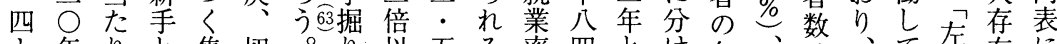
卜年りと集切。り以五る率四とけ名、は、在に ン代出の団羽採上 \%。が・前五九三い言し58示

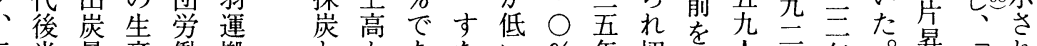

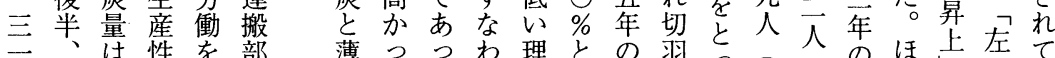

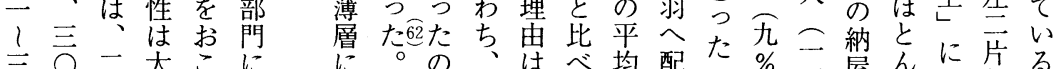

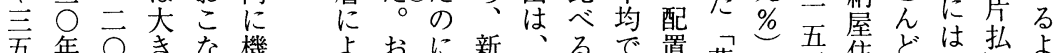

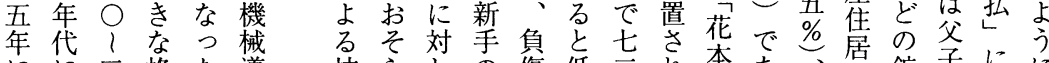

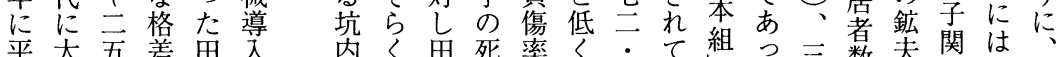

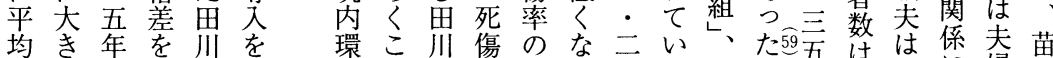
五くに示とお境れが対相つ％た合年五炭に婦字 - 伸平し、少は一稼対てで。金こに年鉱あとを

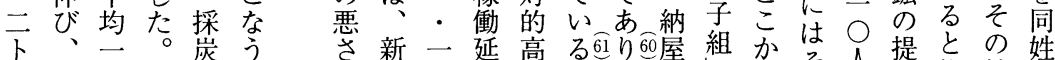

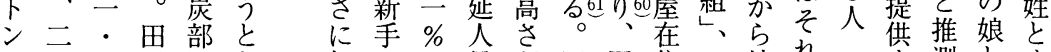
に六四川門と起ので員が田同住坑れぞ势測と亦

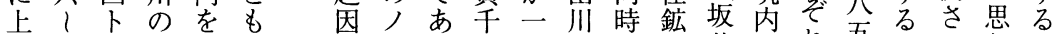

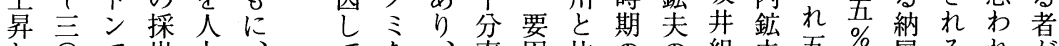

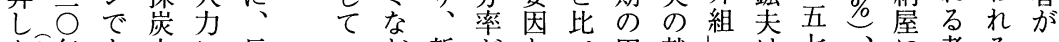
た64年あ夫に長いど新がと㤎就、、は七、に者る一

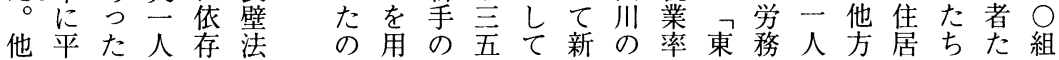




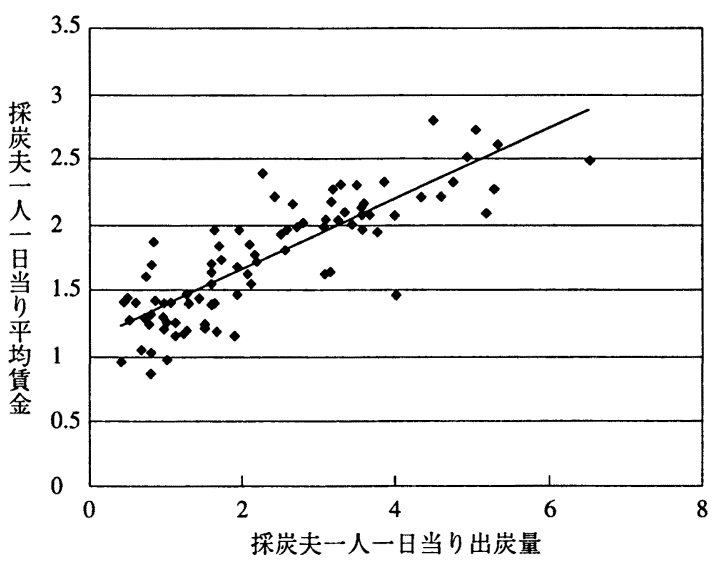

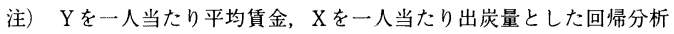
の結果は以下の通り。 $\mathrm{Y}=0.267 \mathrm{X}+1.119$ ( $\mathrm{X}$ の $\mathrm{t}$ 値 $)=14.584$, $($ 切片の $\mathrm{t}$ 値 $)=22.723, \mathrm{R}^{2}=0.703$ 。

出所）「筑豊主要炭鉱現況調査表」, 筑豊石炭鉱業互助会炭鉱現況調査 表」『職業紹介文書」。

図 2 筑豊 92 炭鉱における賃金と生産性の関係
のにて66り性思方 手対新自格と新 の的手賃差二手 賃にが金は人は 金高 三 が賃二而 㤎生西三金旦四 低産! 一当当 との五三反り五 い田年五映四年 う川に年しトに 関の平にてン平 係賃均平拟以均 加金約均り上 み率一約、の・ らが・三田生九 れ高二・川産卜 たく円而の性ン で円採格で

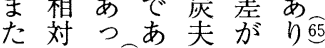
的た荇立あ 図に。た人つ 2 低この二た に生のに日。年 示産よ対当生代 さ性うした産に

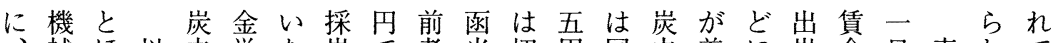
械ほ以夫単た炭で者当切开同夫差に炭金日表れて 禁導ほ上に価とがあのた羽以時のし対を単の 8 るい 止入同み労が考困つ切りご下期一引するお価出にこ さをじて働最え難た羽 ○とでの人かるこを炭示とよ れお費きの\&らで。で・のあ田当れ副な掛函さがう たこ用たイ高れあこ働八賃り、川たる業つけ数れ分に 女なでよンくるりのく金、のりこ金たるかて加 性わ生う七な。熟格鉱と単平平賃と羊鉱こらいる筑 労な産にンつま練差夫 $○$ 価均均金も加夫と商る。豊

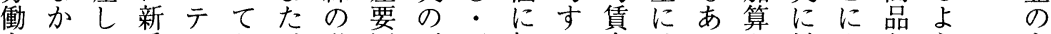

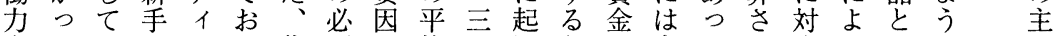
をたいはブり集要に均五因とに大たれする゙なな起要

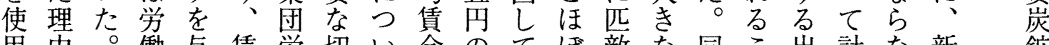
用南。働与顀労切い金のてほ敵な同こ出計な新鉣 では新集え金働羽ては切い一し差表と炭算い手学 き、手約て 単をほ明一羽た・劣に䆓さ硬の

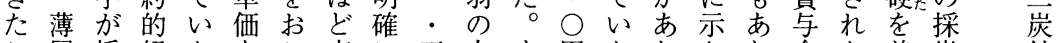
こ層採経たをこ高に五大す四たりさり金た差炭鉱

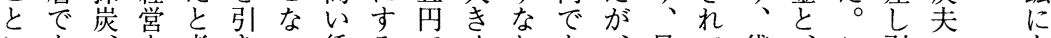

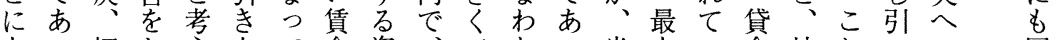

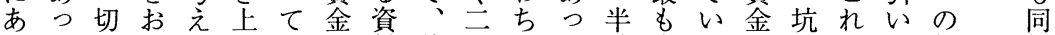
つた羽こらげいが料後つ、た数高るや隹るた賃様 たこ運なれるた支は者にこ。以いよ衛の-正金のの がと搬いるこ切払なは分のこ上方生枠定味支傾

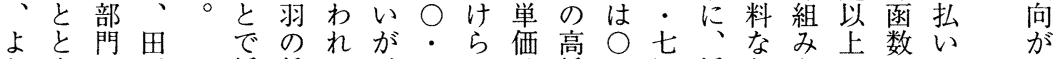

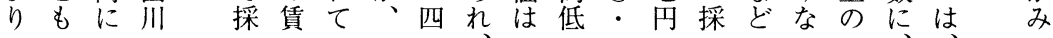


経営史学 第37巻第 2 号

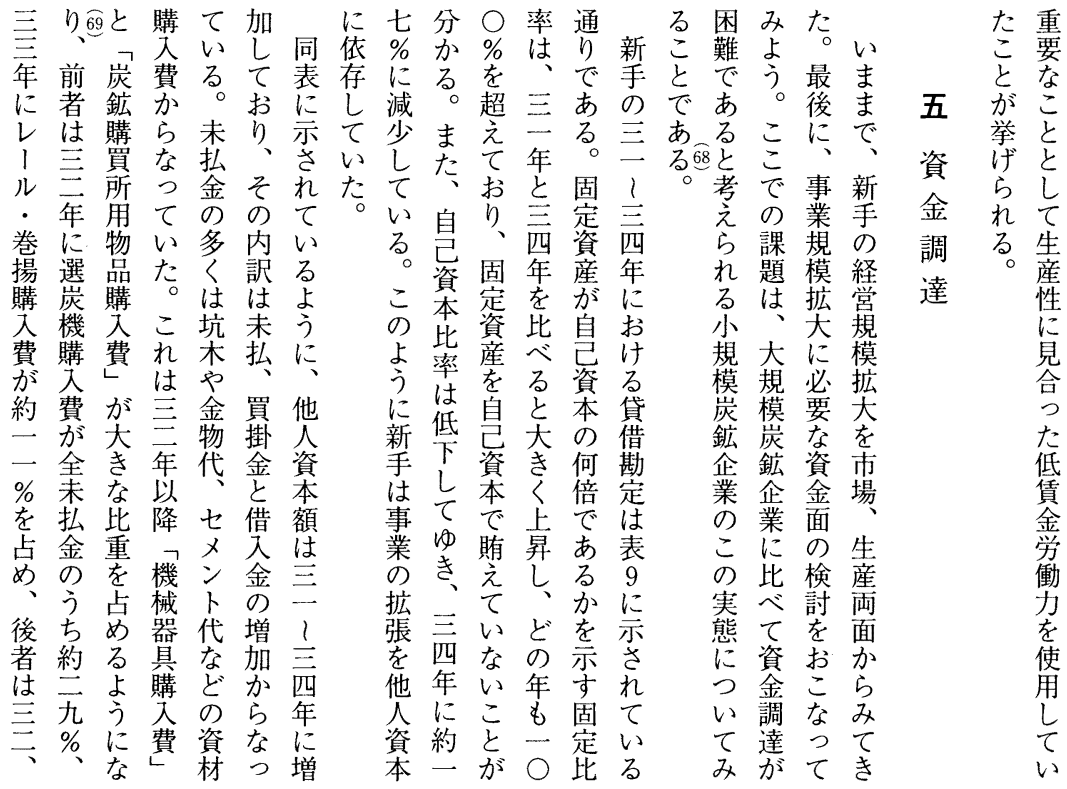

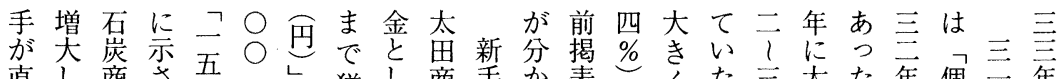
直し商さ五し 猶し商手加表主くた言太た年個二年

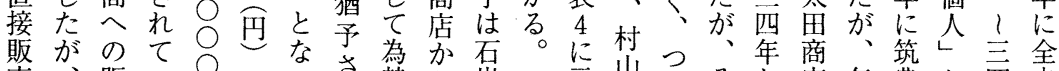

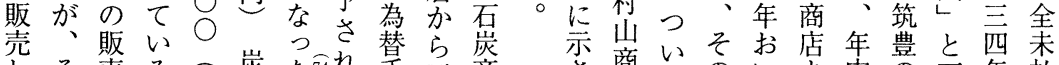

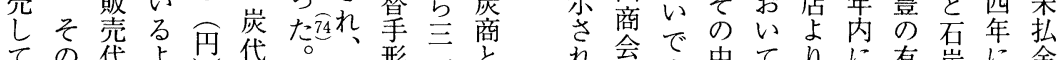

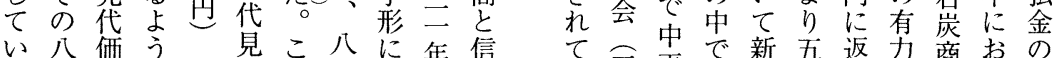

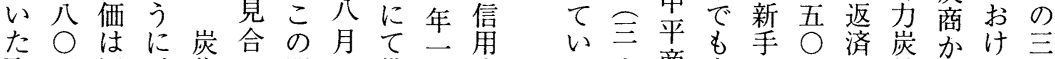

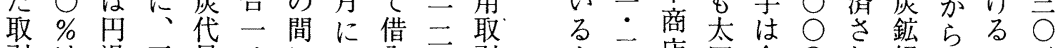
引は滑三見時にほ入司引文店思合○経調一\%

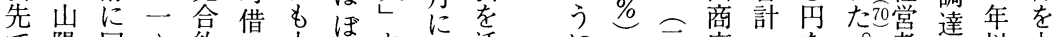
で陽回!約入态半れ活に永店二を著達以占

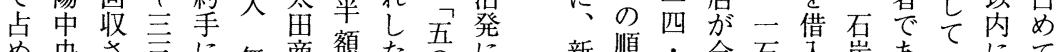
め央さ隹に無商額た吾に発新順・全石入炭あいにて

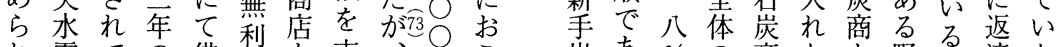

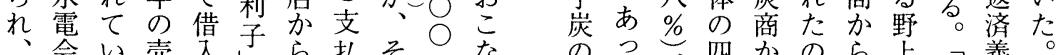

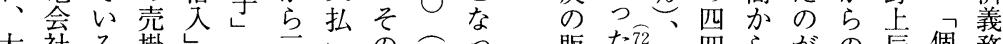

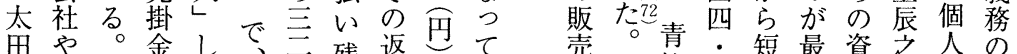

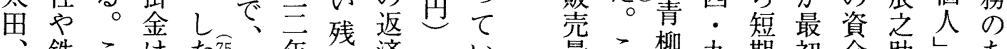
鉄こ美た吾三年金済水い量こ柳九期初金助にあ 中道れほ。三宍金は水た半れ商\%資で調场にる 平省はとま言公っ三選。大ら店を金あ達金つ短

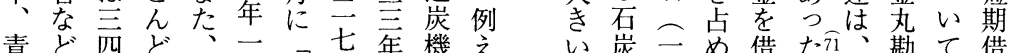

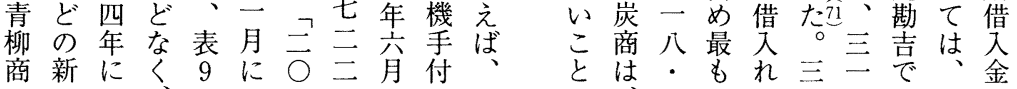


表 9 新手炭鉱の貸借勘定

(単位：千円)

\begin{tabular}{|c|c|c|c|c|c|c|}
\hline \multicolumn{2}{|r|}{ 項目 } & \multirow[t]{2}{*}{ 勘定科目 } & \multirow{2}{*}{$\begin{array}{c}1931 \text { 年 } \\
305 \cdot 315\end{array}$} & \multirow{2}{*}{$\begin{array}{l}\text { 1932年 } \\
393\end{array}$} & \multirow{2}{*}{$\begin{array}{l}\text { 1933年 } \\
403\end{array}$} & \multirow{2}{*}{$\begin{array}{l}\text { 1934年 } \\
480\end{array}$} \\
\hline & 総資本 $=$ 総資産 $(A)$ & & & & & \\
\hline \multirow[t]{14}{*}{ 総資本 } & 他人資本(B) & (合計) & 149 & 223 & 268 & 399 \\
\hline & & 支払手形 & - & 1 & - & 14 \\
\hline & & 未払・買掛金 & 25 & 85 & 67 & 76 \\
\hline & & 仮払金 & 6 & 1 & 3 & 6 \\
\hline & & 商品券 & - & 4 & 3 & 5 \\
\hline & & 坑夫貸金 & 0 & - & - & - \\
\hline & & 借入金 & 118 & 133 & 195 & 298 \\
\hline & & 短期 (石炭商) & 5 & 13 & 61 & 67 \\
\hline & & (個人) & - & 4 & - & - \\
\hline & & 長期 (日本興業銀行) & - & 5 & 29 & 132 \\
\hline & & （信用組合） & - & - & - & 6 \\
\hline & & (大正鉱業) & 60 & 58 & 52 & 41 \\
\hline & & （原田藤太郎） & 53 & 53 & 53 & 53 \\
\hline & 自己資本(C) & 鉱主 & 156 & 170 & 135 & 81 \\
\hline \multirow[t]{12}{*}{ 総資産 } & 固定資産(D) & (合計) & 262 & 276 & 282 & 360 \\
\hline & & 鉣区 & 100 & 100 & 100 & 100 \\
\hline & & 起業費 & 162 & 176 & 182 & 260 \\
\hline & 流動資産(E) & (合計) & 53 & 117 & 121 & 120 \\
\hline & & 銀行·金銀 & 1 & 110 & 76 & 33 \\
\hline & & 倉庫 · 残炭 & 41 & 1 & 20 & 20 \\
\hline & & 坑夫貸金 & - & 3 & 9 & 14 \\
\hline & & 売掛金 & - & - & 5 & 38 \\
\hline & & 仮受金 & 10 & 3 & 11 & 11 \\
\hline & & 商品券 & - & - & - & 2 \\
\hline & 固定比率 (D /C) (\%) & & 168.1 & 162.1 & 208.0 & 444.8 \\
\hline & 自己資本比率 $(\mathrm{C} / \mathrm{A})(\%)$ & & 51.1 & 43.3 & 33.6 & 16.9 \\
\hline
\end{tabular}

注）1.1931年の総資本額と総資産額は一致しないが，そのままにした。

2. 当期純利益は「鉱主」に含まれると考えられる。

3. 1931年, 32年は 12 月, 33 年, 34 年は 11 月の数値。

4.一は 0 を示す。

出所）前掲各期「決算書」。

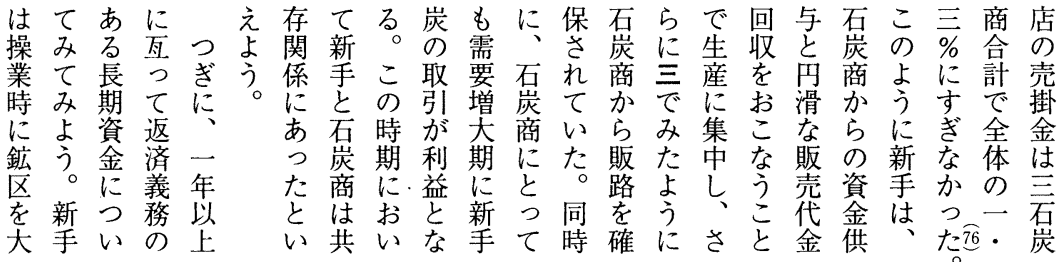


経営史学 第37巻第 2 号

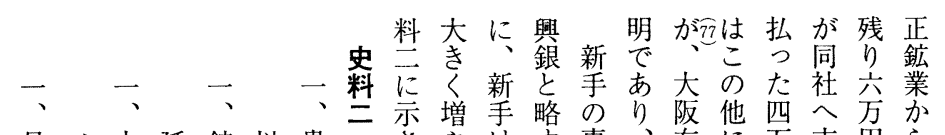

シモ売月, 大延鉱以貴劣やは守事、在に方支出ら

願, 先別契过長区外殿れし興業㧍住も円払は一

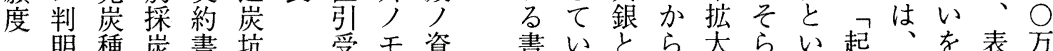

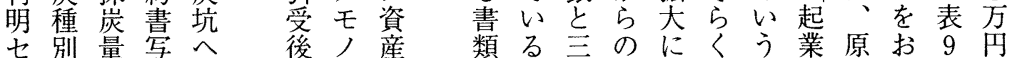

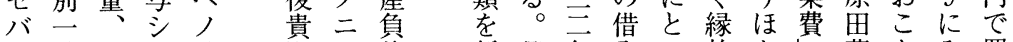

御覧使鉱殿テ債新興年入う故から藤なみ買

通表角区結乎銀加てななとなる 収

知公人売於構可 ○はらで最ど勇し郎てれし

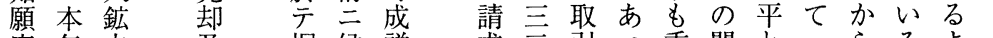

度年夫矢掘候詳求三引う重関と二らるよう

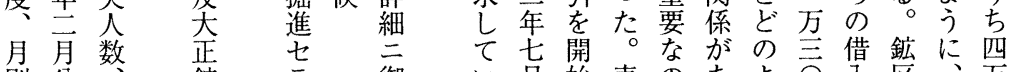

別分鉱 ラ 御い月始表のあある入 入

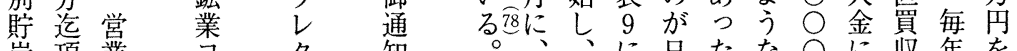

炭頂業当多知。、にたな収年を

数戴費リル 相融示本の関円よ費の即

量致内人本願資西さ興で係をつの返金

毛訳鉱卸度調年れ業あに借たう済で

併候明区資查にて銀乃あ入少額支

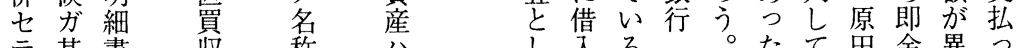

テ其書收称公父るたて田金異っ

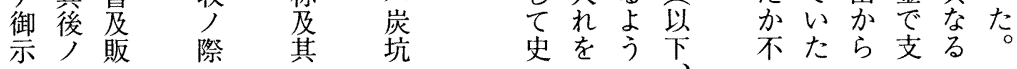

\% た対卜石て

ほ興テ比等なこ同同鉄

ど銀直較

での接的担つで債二納 あ石貸少保た当務対孷

、産与なシ三、弁ル金

同業成〈な三銀済債公

時 へシ、一年行三務同

期 の居令般頃 か充方社

に貸ル令金の崖当担新

お乞モ旦融日炭可保新

け出, 当市本鉱相卜手

るし八地場銀へ成シ炭

興額殆方寻行の事テ鉱

銀はド銀り当融卜貴

の、し 行直調資致行筆

中三な業接查は居三者

小三以者資査一候於注

商桨態金は般余,

業西態代供的䒫貴

融年あ炭給鉱お理社

資でつ坑 7 区 こ 受

鉱全た体業仰設わ須興

業のま旦備れ 上
鉄手三棟こが営ら年

史道加玶少信業で五は

料省ら、前内角状あ月じ-

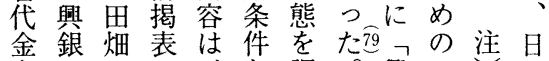
もへ 7 、と調。興 ᄀ本 担の雑に新な今゙業炭二電 保草示手つ、の銀坑関力 と承地さのたさよ行以ス な諾・和全。らう鑑外儿八 つ書原て資興にに定ノ買幡

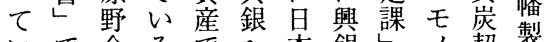
いで合るでへ本銀上, 契製 た要あわ機あの電はが二約鉄 るせ械る担力尔新書所 史元設鉱保、林手結写 料三備区は八のを構シ鉄 三三立二、幡資 实と道

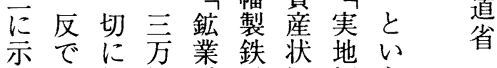
さあ加坪財況捧う欄 れ己充、団鉄户見の 外 い。宅美と省季しは、架

るま地社さへのてす筆

うた二宅れたの資いで に新九严売とか同者 
表10 新手炭鉱の損益勘定

(単位：千円)

\begin{tabular}{r|r|r|l|c|c|c|c|c|c}
\hline 年 & 炭代収入 & 雑収入 & 計 & 総経費 & 差引利益金 & 総資本 & 自己資本 & $\begin{array}{l}\text { 総資本経常 } \\
\text { 利益率 }(\%)\end{array}$ & $\begin{array}{l}\text { 自己資本経常 } \\
\text { 利益率 }(\%)\end{array}$ \\
\hline 1932 & 261 & 12 & 283 & 373 & -90 & 393 & 170 & -22.9 & -52.9 \\
1933 & 501 & 5 & 506 & 465 & 41 & 403 & 135 & 10.2 & 30.5 \\
1934 & 502 & 29 & 531 & 462 & 69 & 480 & 81 & 14.4 & 85.3 \\
\hline
\end{tabular}

出所） 前揭各期「決算書」。

貸よあさち埋鉱鉱とに満㛜述満ど保準側をてし部 い出うつれ採蔵山脈考対たししたへと備の㧍、い85門

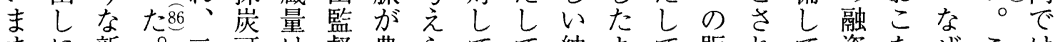
まに新。二可は督豊らてて納よて販れて資なぜこは で応手お四能五局富れ信い炭うい売たい条つ興のほ みじのそ年量三のでる角る条にたが鉱な件た銀よと てた将ら間は○調あ。供こ件鉄と興業いをの学うん きの来くの方查つ第与とが道考銀財が考だ新など たで性、採四卜でた严をであ省えの団、慮ろ手状な よあを興炭○ンはこに㧍興りへら融と第守うに況か うろ見銀が方、と、銀、の資鉄一るか信下っ にう込は可卜そ新で新なはこ販る条道に資。用にた

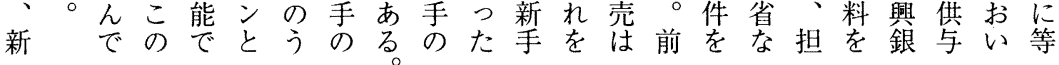

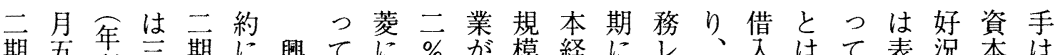
期五利至期に興てに\%が模経にレ、入はて表況本は に○息至のよ銀いは、三崖常大バさ分、い 10 期比他

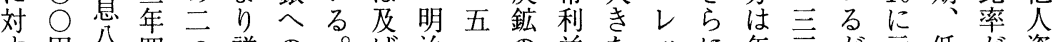

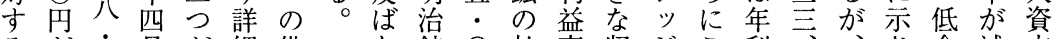
るが充月が細借 な鉱 ○払率収 ジこ利、、さ金減本

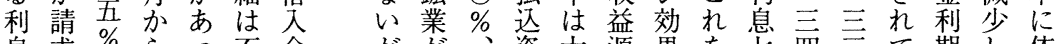

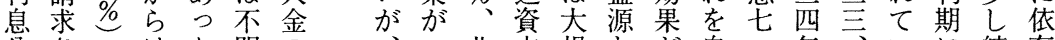
分さてはた明のは一北本替とが自・年、いに続存 四注でじで返明○海利模なは芑五に三る妥けし 七るあま現あ済治: 道益炭つた資器興西通当たて

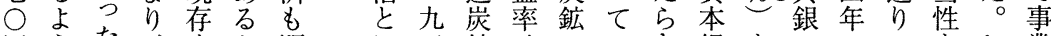
円うた、吉が順ほ ほ 鉱はにいき経をのにでをし業 にが同る、調方で汽、元る心常年黑あ備か心 年な同年資興に 息 、年月でかこ等、七鉱るで資率本で転利いこを

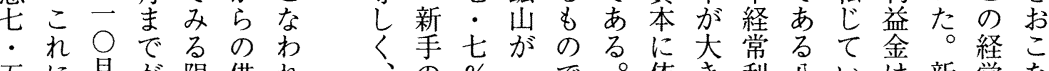

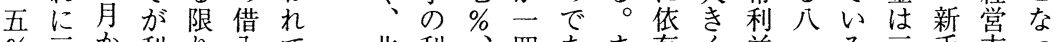

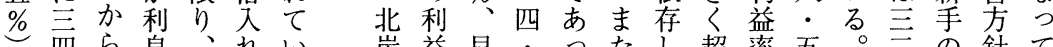
西ら息、れい炭益貝自ったし超率五。吾の針て

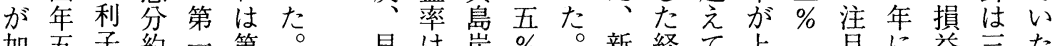
加五子約一第。貝は炭 \% 、新経て上气貝に益主た

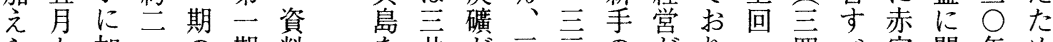
らか加二の期料を开加三三の总りつ四べ字関年め

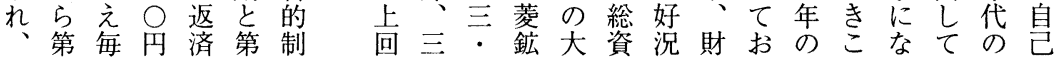


経営史学 第37巻第 2 号

長に使を生ル炭增こみ大所 期資用お産の機加とてき新い 資金しこ面アををといく手ま 金面たなにウ導石、く経炭ま 供で労つおト入炭地と営鉱で 与は㗢てい多し商理、規は検 が、集おて। 経石約り、と鉄販に一を 営炭的、、し道売有に拡年て 嫢商経こ第て省す利炭大かき 模営れ吾自笛で質し占た

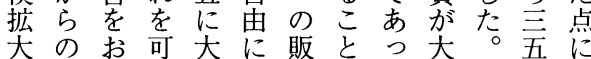
を運こ能規生売でた炭こ年つ 支転なに模産に販こ鉱のにい え資つし炭が成路とに市かて て金てた鉱で功を、匹場け要 いのい理ときし確第敵面て約 た供た间たた保云方に大し 与ことほここしにるお規て ととし同とと、景ほけ模み とにてじを気どる岸よ も古低コ挙第と回良拡鉱う につ賃スげ四、復好大の。 た金上らに第期で要寡小 興。労でれカ兰のあ因占林 銀第働生るルに需つか下鉱 の六を産。テ選要たらに業

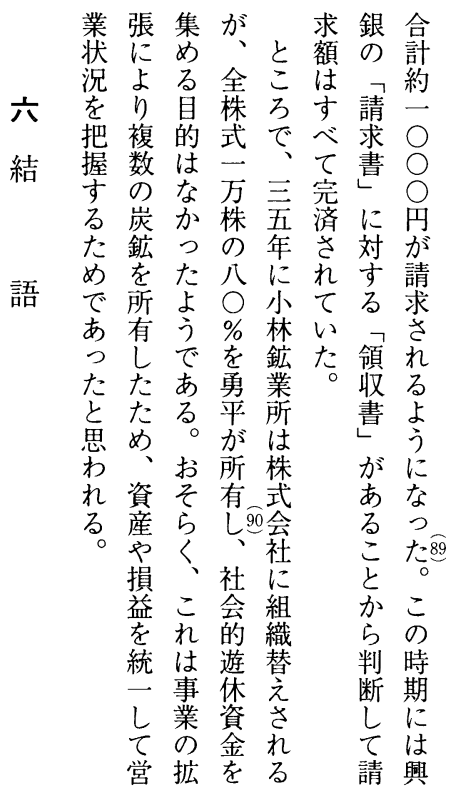

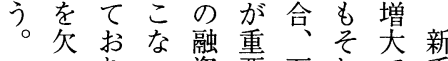
いりっ資要石れで手 て、てはで炭があの い三い重あ商必つ経 る井た要っにずた営 たやとなたよしょ規 め王い意。るもう模 興菱う味ま販生に搪 銀よのも高のわに 加うのつ新確拡れ最 らな、て手保大るも の財事いのやに。重 融閥業た経鉄結し要 資系拡。党道びかな は企張新嫢省つし、要 不業に手模へく、因 可の多は拡のと需は 欠よ額労大販は要 でうな㗢に売限が景 あに資集とにら拡気 つ旺金約つ成ず大回 た盛を的て功、し復 とな必経興し新た期 い資要営銀た手との え金と老加のし需 よ美しおらと場市要
うりと石がう金炭なての商 、゙炭增、供鉱いい運加加 こ安商大㩁与に新た転らえ の定間す取の資手。資資て 時しのるの見金炭石金金 期た競こ主返供を炭にを新 に石争の体り与確商よ供手 お炭も時とにを保につ給と け供激期し炭お专とて等石 る給化にて鉱こるつ増れ炭 新をすは解かなこて産る商

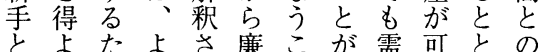
石うめり栖亡有要能毛関 炭と、多るなで利增とに係 商し炭くこ石一に大な円は はて鉱のと炭手な期り滑重 共い合も買販るに、に要 存た資炭あい壳。新さ販で 関と金をつ取権石手ら売あ 係考供確た勿りを炭にに代っ あえ与保。を獲商資販金た たれ拈よかこし資供も回新 とるこうしな学与確収手 い。なと、うそのを保しは

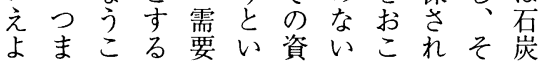


格で賃企に経新し対す三手経へ続のリ幸氾期 差あ金し業よ営手かす新る七し営のけで為三濫かし はり労かのつ替がしる手と年し者返るあま二シのらか

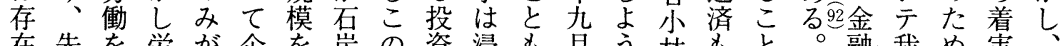
在先を労が企を炭の資浸も月等林もと。融我め実

寸行利㗢発業拡市偶を水ににと勇滞がそ其ガにに新 る研用面展に大場発圐勇小し平つでの他社水事手 。究しに的優し的こ免平林たはてき後三重害業の

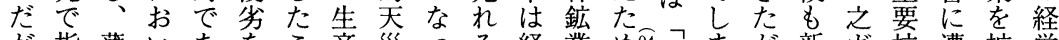

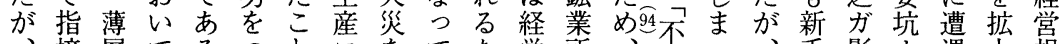
、摘層てるつと学ててた営所、撓つ、手影ナ遇大替 新さや新とけでス除いめ権っ重摬た环修は響ルしし模 手れ手手はるあたけなに株役屈た復新学新てて拡 側て掘はいこる。面ばか高重なた出た焦坑来手しき大 かい採、えと。で、つ台役はち加が事を涪本またに らる炭大ながこ大本たにた九かべ、に開所坑うがは みよの賛いでの嫢稿た坑ち州らテこ多い謂ノ。限 るうた模こきこ模でめ、に採批去の額て非罹つ三界 となめ炭となと炭最、を奪炭判㨏よのい常災ま吾が 豊大負鉱でいは鉱も経開わ放う炭た事三り年あ 富炭傷とあこ主営くれ株お坑な金た態多っにっ

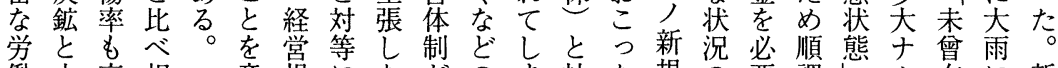
㗢小高相意嫢にたがのま社た替の要調しル有に新 力炭い対味模競い動りう名。事中とにと損了手 を鉱悪的しの争こ摇スた旬をそ業でし出な害大るは 利と条に、大 用の件低大小ては位に更て着、銀をた蒙不川業

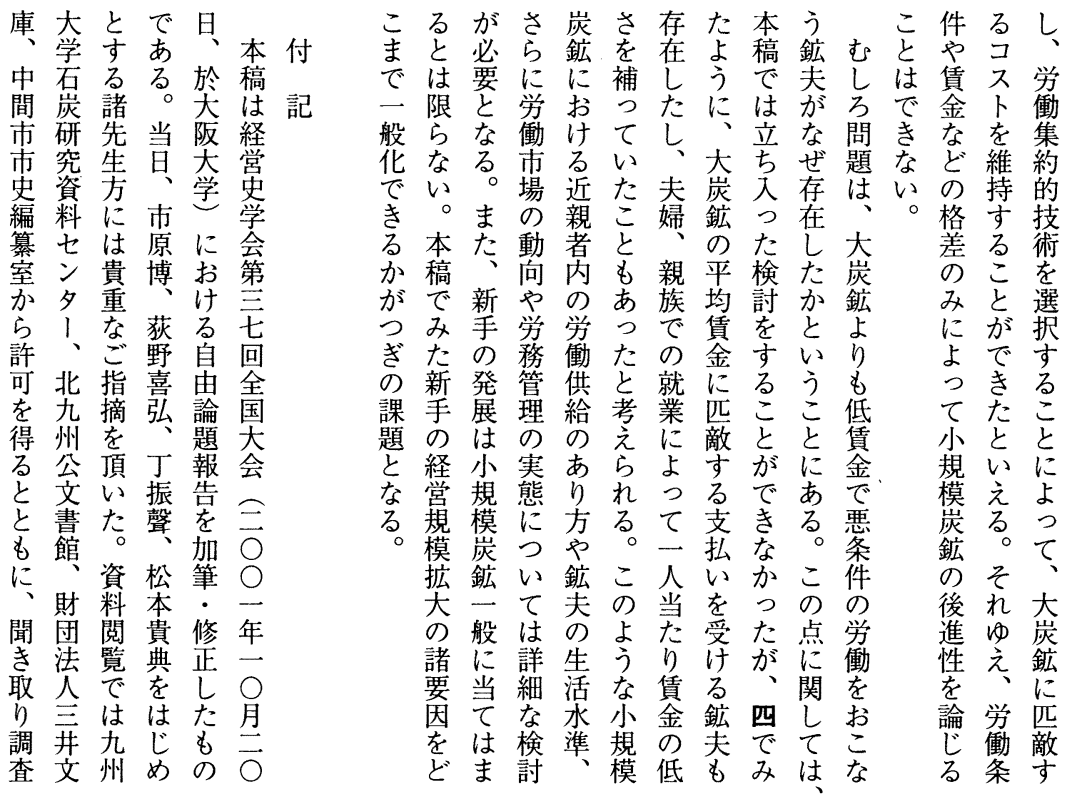




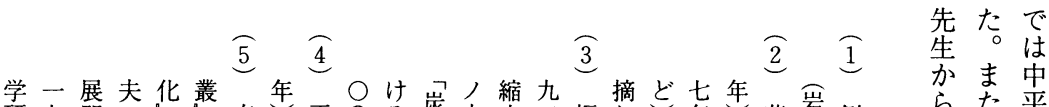

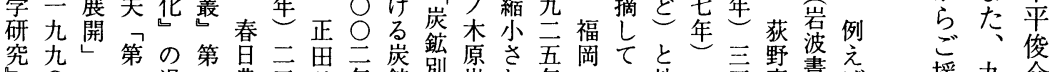

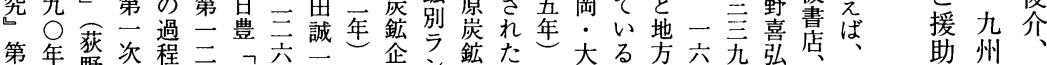
第年野世程豆二窝一を企シ鉱た大る。方九弘六、助州

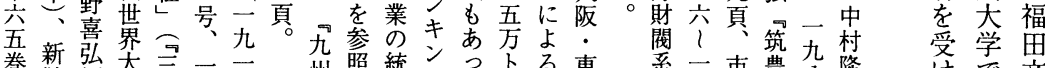
巻新弘大至- - 州照統グっトる東悉市市豊八隆活で文 一拓編戦开九文七石。計年だ。表京 九生戦期庫尣代 九应前か論年に 七麻期方䯌年书 年生筑昭最、沙 商豊和第春る 店炭恐旦 分鏣慌四豊开 石業期号了鉱 孷の否号岸 貶経至二況炭展 堂営九敇開 す労貝公鉱開 九㗢覀年引 大啓業、る开 学文経永っ文 経社棠江合庫 観に、模た仙 察にこの台 心市大. 五いら井企札 工立本業槕 ネは例洞の各 旮儿外炭事鉱

州ギ長に鉱業山

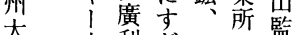

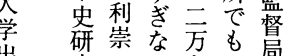
究尔尔局 第間大規年鉱 第間 な替年鉱 七晿临覧

九㤐本詳三事覧 済、の畺理論

二扔な油が二
宸六原崖九

釷貪博鋝年尾

頁崖資。高

島な鉱関

鉱おの係

業市学史

学原社旮

衝財会州

条閥史大

件悉多学

お鉱賀版

け一出会

る 版

格 菱

差鉱一九

を業九九
たの子、

末資福

尾閲 田

な覧洋

がの子

ら際各

感、民

謝東 加

を定ら

申宣貴

ᄂ 昌重

げ新お

ま鞍話

。生伺

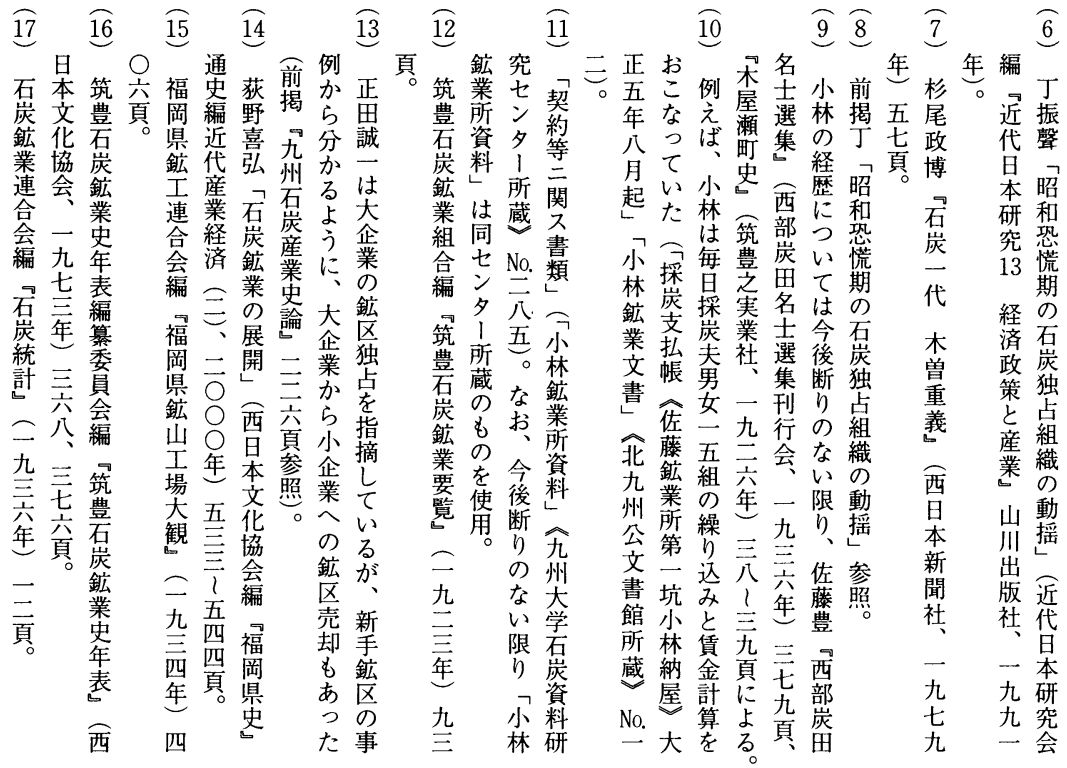


$\widehat{30} \quad \widehat{29} \quad \widehat{28} \widehat{27} \widehat{26} \quad \widehat{25} \quad \widehat{24} \quad \widehat{23} \quad \widehat{22} \quad \widehat{21} \quad \widehat{20} \widehat{19} \widehat{18}$

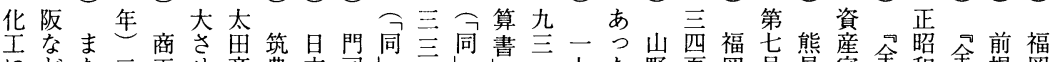

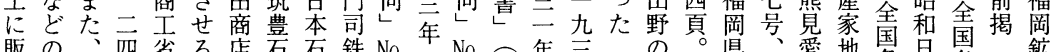
貶の、西省る店石石鉄 No.

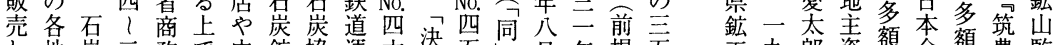

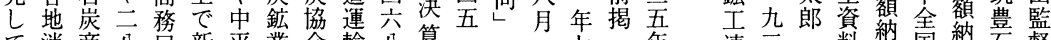

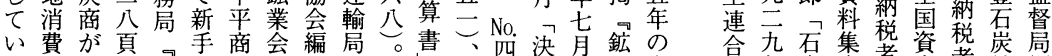
た地直。商に店編編算口区出

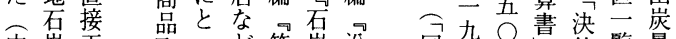
中宸工取っど筑宸浴同旮包算覧量 平商場引ての豊統線 商とへ 組有有石計岸

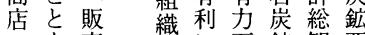
の克荒に石鉱観要

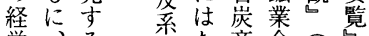
賞本嚗統た商会二元

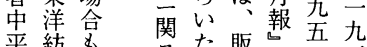
平紡名釜た販心五九

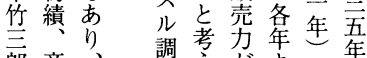
郎帝 の国中 息人平 絹商 で帝店 万国大 調考怔上年

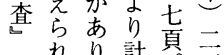
一れ就頁吾 旮。貶算 吾 №.年一合書。岕 会年炭成者産者鉱編

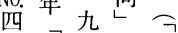
六決要 No. 小 算二四林 、書 年四 鉱 黾年省方 九茼 $\mathrm{O}$ 啠資 九同 1 一瓷雉 西 No. 三㭉新

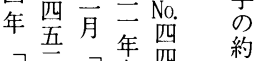
決气決年署緯酉

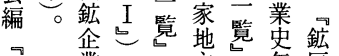
福業一至年区 貝就六无喪九表覧

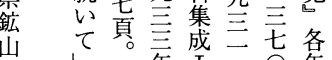

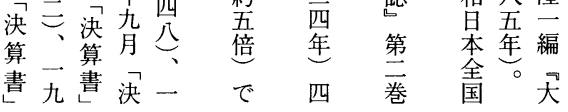

$\overparen{39}$ $\overparen{38} \widehat{37} \overparen{36} \overparen{35} \overparen{34}$ 関二州照州野の九独水龵一喬

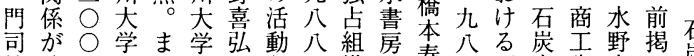
鉄論○石た経々と年織涛四石産省良灭颣

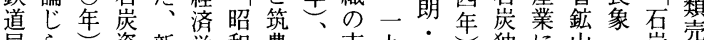
局ら資新学和豊荻市九武、独に山崖賣

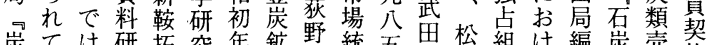

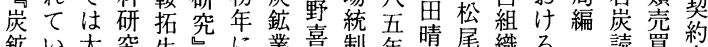

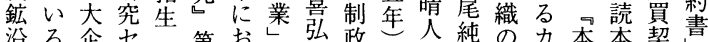

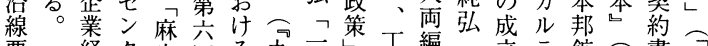

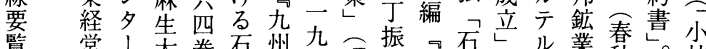

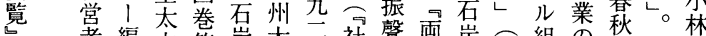
著編吉第崖大学社聲両岸組の社鉱 二

九麻エ炭六業経年経重戦業会に勢—

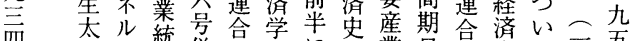

四含ギ統併会研に学業期会済い二五

年吉丮制会研究学統本会学は九公

、と史向指究、汁第制の昭学は产年

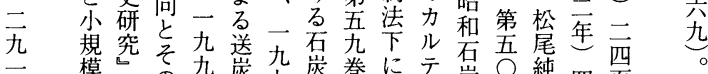

頁経第論八制九鉱第扔ル株巻弘四頁

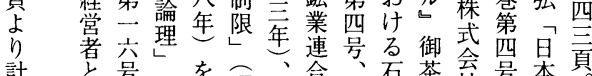

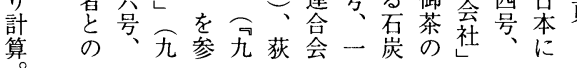

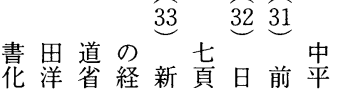
ᄂ子嫦手。本揭俊 た的者の銀各介 か販冬事衡期氏 ら売あ例調 の 二をると查決御 ○止福は局算教 ○田異編書示 ○な定な 年い次る 二よはが

云に炭鉄 の鉱価道

聞長上省 きに昇合 取命期の りじに販 にても売調 


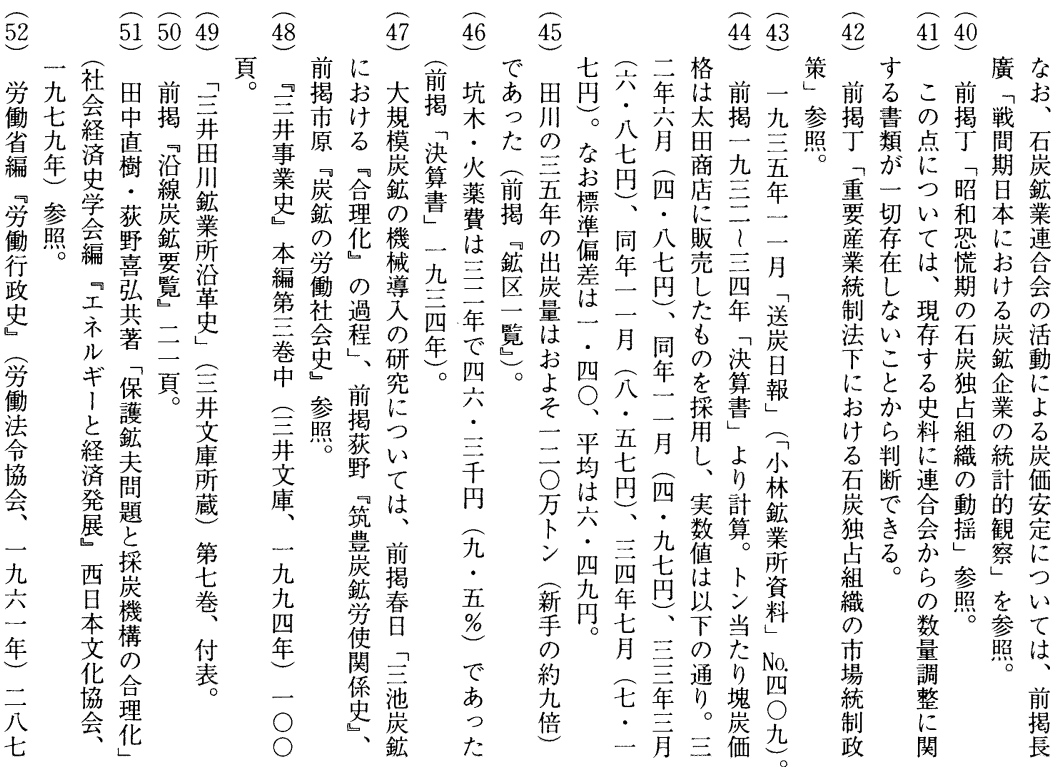

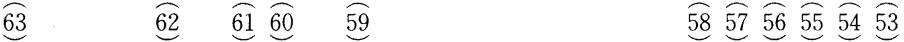

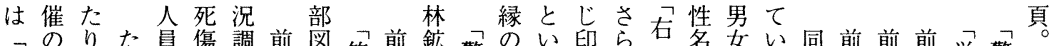

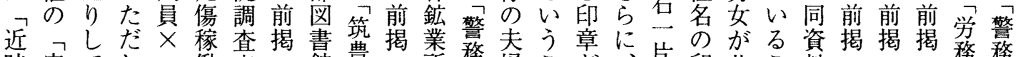

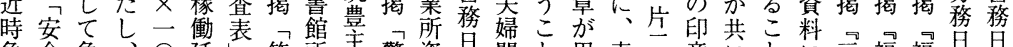

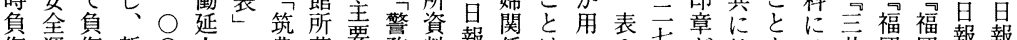
傷運傷新○人へ豊蔵要務料報係はい8 8 草就かは开岡岡報報

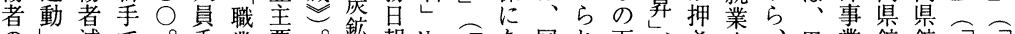

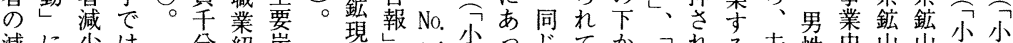
減に少は分紹孷 少上策鉱率介鉱 はつを夫\|文現 見ておへ る促こポ ベさなス きれっ夕 \& $\tau \tau$ । のいいや あたた入 り こ晊 とうたに 死畫洗 者車查 数京衣、 $+大$

負学筑

傷 経 豊

者済石

数学炭 れたこ参

て結れ洋 い果はを る互 義 新助務

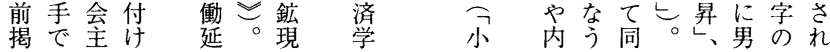
部 鈸 $\div$ 図業 全書互 鉱 館 助 夫所会 稼蔵岸 洗、、云林っじてか家いら右てる場婦の性史山山禁禁

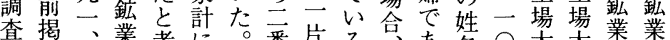

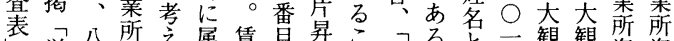

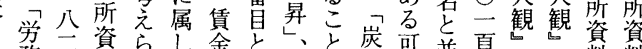

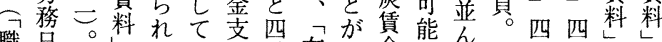

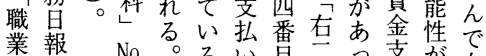

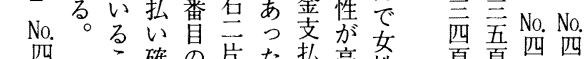
芥。四气確の片た払高性

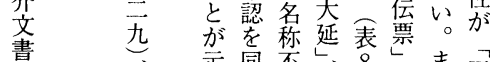

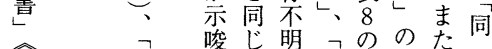
西筫四四

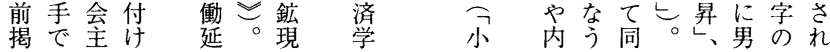

菄
唆じ明后の印た 记章羾乭左性異名 、草に片主名なし 親打も六片のると 族こ全延三上名記 
$\overparen{83}$

$$
\widehat{82} \widehat{81}
$$

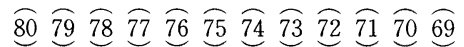

$\widehat{68} \widehat{67} \widehat{66} \widehat{65} \widehat{64}$

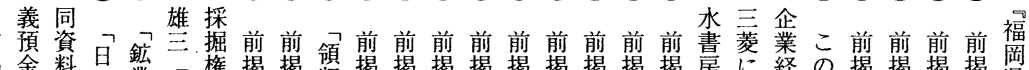

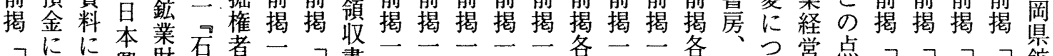

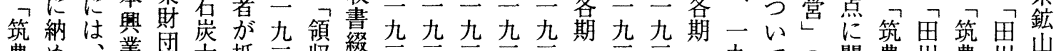

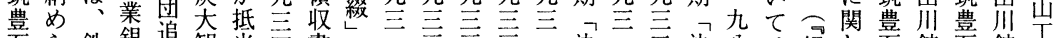

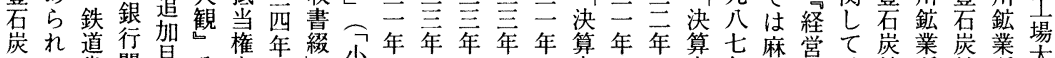

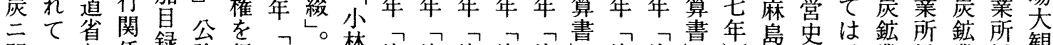

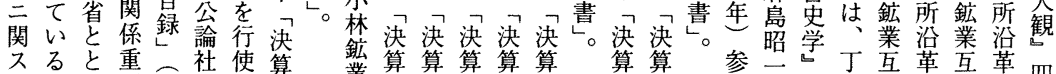

ル。を要尔守書

調に書尔一る書。

查公類鉱九場

幡鏣四合鏣

六製兮哲年に設

1 釿小資年立団

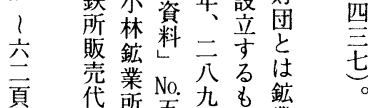

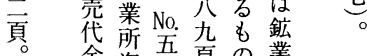

金資吾頁ので業

藏料严。西当

鏣算算算算

業書書書書書 醋書

㓓

No.

参照編第振助史助史塄

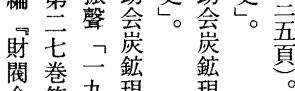

小四見基

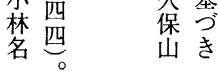

筬粟九現

融豆 訜

造 年查

の一代表。

跤九旦

研光本

究年に

御三光

茶井炭

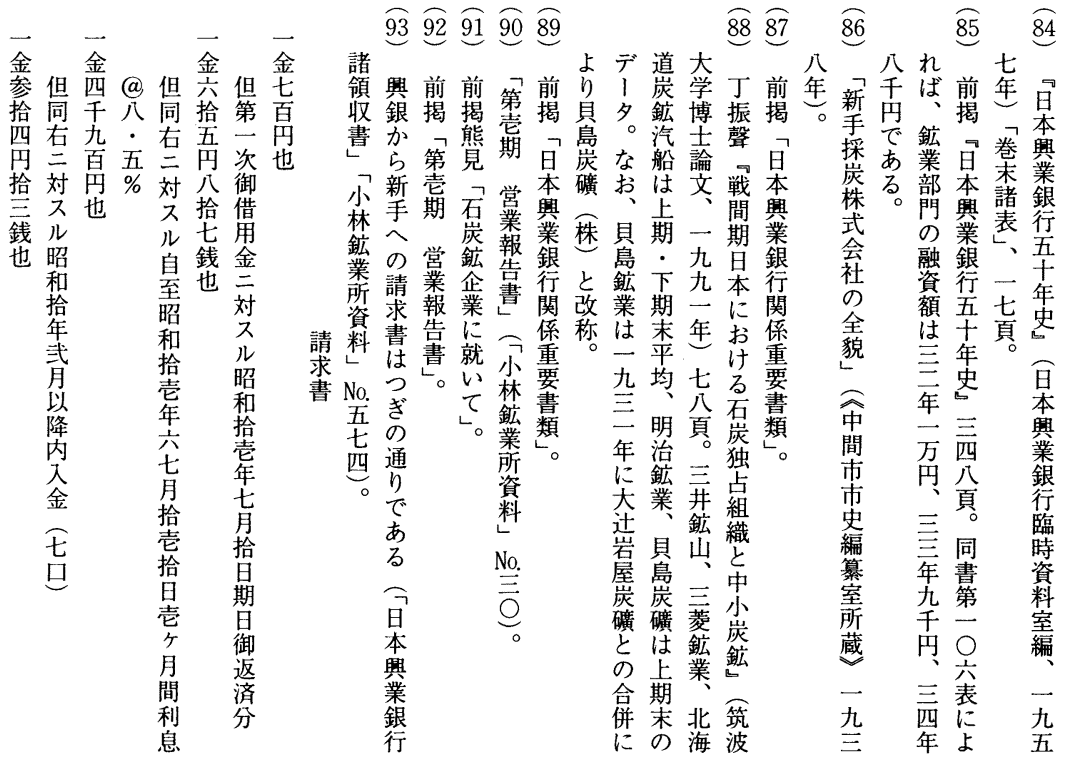




\section{5 $\widehat{94}$}

山当際西中商鉱門略常経に小 務る経杲|会嫦携州揭林林 のの営矂の老わ採鉱勇 手は亳財株重扔つ炭第業苹 に稀野界式鎮こてて壱株殿 よに見動譲でなき秼期式

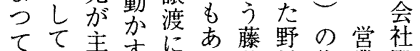
てて、主すにあ滕野代掌殿 さそ皃よった鉱山表報 れのて内藤業謙取告 て実お一支并伊示締畫。 お的り苜配蔵然は り経現九さ兄のつ小 、営現九さ経た林 、は社年れ 営。鉱 殆犬長一た大亭同業 ど丸藤二西量で社の 独重井二西公あは設 裁役伊五夏幕り言立 な的藏頁本增、北当当 快り甘し済の九にか 腕殆亦加新際州筑 をど社し、聞に若豊会 振野務、部、松で計 ひ見に実編|の炭部

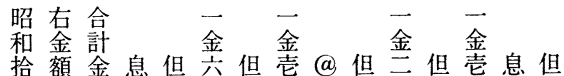
拾額金息但六但壱@但云但壱息但

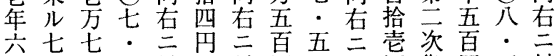
月月千五対五対円 $\%$ 対问御 円五対 武拾九 \% 拾 九旦百ル四ル

日迄七自銭昭 拾至也和 御吕昭拾 入四

金銭 被也

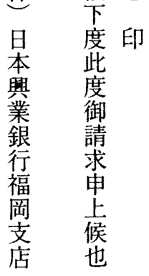

和

拾 武

年以

六降

月

拾

金

t

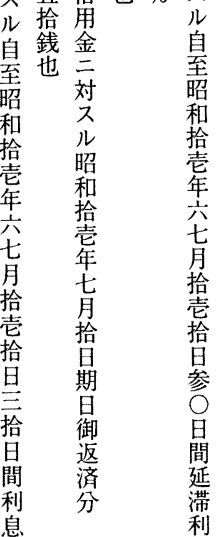

石手規論来 啒に模社つ 岸よは鉱し 大つ、業て

観て野界い 再胃名た 五び山士た な六辺経鑑瀧 が頁鉱棠編菊 ひ。篹一 ろ拿こ部鉱 - 併旦一業

と艺縮九界

し れ小名 た 大し 九士 か 站年、鑑

大拡、戦九前

阪 亡時九頁編

学前製新无

学揭に手州

院久藤の人 保井経物 山の営公 


\section{THE GROWTH OF THE MANAGEMENT SCALE OF COAL MINES \\ DURING THE INTERWAR PERIOD: \\ THE CASE OF A SMALL-SCALE MINE}

\section{Toshitaka Nagahiro \\ Osaka University}

In most previous studies of the Japanese coal industrial history, it is assumed that small-scale coal mines were undeveloped. Large-scale coal mines, such as Mitsui and Mitsubishi, were thought to have monopolized the market during the interwar period. However, there is almost no empirical study that analyzes small-scale coal mines. Therefore, this paper examines the case of Arate coal mine, under small-scale management in the coalfields of Chikuhou during the interwar period.

The coal market share of Arate was greatly extended under the oligopoly of large-scale coal mines from 1930 to 1935 . In this study, this factor is analyzed from three angles: a market, production, and finances.

What should be emphasized is that Arate produced high-quality coal that was equal to that of large-scale coal mines. Arate operated under a labor-intensive system, using low wage earnings, and was became able to compete at the same production cost as large-scale coal mines.

That is, Arate competed on an equal footing with large-scale coal mines, in both the market and production cost, and grew in management scale. This paper thus presents a critique of the historical image of small-scale coal mines as undeveloped. 